\title{
The Influential Factors of Taiwan SMEs' Clustering Keystone Business Strategy-The Perspective of Business Ecosystem Using FAHP
}

\author{
Ming-Kuen Chen, Chung-Min Wu, Lee-Shing Chen * ${ }^{D}$ and Ya-Ping Huang
}

Citation: Chen, M.-K.; Wu, C.-M.;

Chen, L.-S.; Huang, Y.-P. The

Influential Factors of Taiwan SMEs'

Clustering Keystone Business

Strategy-The Perspective of

Business Ecosystem Using FAHP.

Sustainability 2021, 13, 10304. https:

//doi.org/10.3390/su131810304

Academic Editor: Natalia Yakovleva

Received: 24 June 2021

Accepted: 2 September 2021

Published: 15 September 2021

Publisher's Note: MDPI stays neutral with regard to jurisdictional claims in published maps and institutional affiliations.

Copyright: (c) 2021 by the authors. Licensee MDPI, Basel, Switzerland. This article is an open access article distributed under the terms and conditions of the Creative Commons Attribution (CC BY) license (https:// creativecommons.org/licenses/by/ $4.0 /)$.
College of Management, National Taipei University of Technology, Taipei 106, Taiwan; mkchen@ntut.edu.tw (M.-K.C.); cmwu@ntut.edu.tw (C.-M.W.); t106749009@ntut.edu.tw (Y.-P.H.)

* Correspondence: t103749009@ntut.edu.tw; Tel.: +886-932019575

\begin{abstract}
Small and medium enterprises (SMEs) are usually lacking in resources and technical capabilities. Clusters are considered to be a common development pattern to promote resource sharing and information exchange among SMEs. The business ecosystem provides a new perspective for contemporary companies. Through the symbiosis and evolution of the biomimetic system, companies can pursue their own interests on the platform and, at the same time, promote the growth of the overall ecosystem. This study used manufacturing and service Taiwan SMEs as the sample population, and utilized FAHP (Fuzzy Analytic Hierarchy Process) and survey questionnaire methods to explore both the factors that influence the analysis and comparison of the keystone business strategy between manufacturing and service industries and the reasons behind it.
\end{abstract}

Keywords: SME; cluster; keystone; strategy; business ecosystem

\section{Introduction}

In 2016, most countries started to strengthen and promote the recovery and revival of small and medium-sized enterprises (SMEs), and are continuing to encourage innovation and entrepreneurship for SMEs. SMEs in the United States are optimistic about the economy and have confidence in the growth of their companies. Meanwhile, Mainland China has issued the Promotion of Small and Medium-sized Enterprises Development Plan (2016-2020) to promote policies and reforms for the enhancement of SMEs' entrepreneurial and innovation capabilities. Consequently, in order to maintain the sustainable development of SMEs, Japan has promoted a number of measures to support the expansion of SMEs in emerging markets overseas. Based on its previous achievements, Korea pooled resources and fostered SMEs, and worked hard to allow its citizens to enjoy the achievements [1].

SMEs have always been the backbone of Taiwan's economic development. According to the White Paper for SMEs [2], the number of domestic SMEs has reached 1,248,000, accounting for $97.68 \%$ of all entrepreneurs (the manufacturing industry $18.67 \%$ and service industry $80.42 \%$ in SME). SMEs' sales are 30\% in total sales. The manufacturing industry's sales are $49.41 \%$ and service industry's sales are 50.42\% in SME. SMEs' human resources is $71.63 \%$ of total human resources.

This shows that Taiwan is a paradise for SMEs, and that they are the engine of Taiwan's economic development; however, financial capabilities and human resources of SMEs are not as adequate as that of large companies. This means that SMEs face more challenges, including changes in the economic environment. The reason why industry clusters in Taiwan are ranked first is that SMEs in Taiwan account for $98 \%$ of entrepreneurs. Due to the constraints of scale and funding, SMEs form a meticulous synergy network and play significant roles in competition through "professional division of labor" and "reciprocal complementarity" in their development processes. This competitiveness does not come from the production capacity of a single company, but the interaction of the entire system, 
which shapes a stronger competitive advantage [3]. Clustering and the supply chain are the key components that help to shape competitiveness among entrepreneurs. The biggest feature of Taiwan's manufacturing industry is that many center factories and cooperative factories cluster together to form a complete center-satellite system. Each system functions like a mutually beneficial symbiotic business ecosystem. Enterprises are no longer pure opponents, but are competitors in ecological systems [4].

Industrial clustering refers to the grouping of the same or similar types of companies in a geographical area, which is not limited to new businesses or specific high-tech industries [5]. Since the proposition of Porter [6], the advantages of clustering have been widely used in many fields. Through the formation of clustering, enterprises can reduce input costs, develop common suppliers, cultivate a professional labor force, and produce technical knowledge spillover effects [7]. Through clustering, social embeddedness can be generated, economic activities among members can be promoted to reduce transaction costs $[8,9]$, and elastic production efficiency can be promoted.

Iansiti and Levien $[10,11]$ believed that the most cited examples of successful companies who utilized the business ecosystem, Apple and Cisco, are the new models of the modern enterprise. Both companies think that a new concept should be established for the business ecosystem to work and for the creation of strategies. The concept of a business ecosystem can be explained by metaphorizing the biological communication in the ecosystem. Ecosystems have also been cited for research in other fields, such as digital ecosystems [12,13] and social ecosystems [14].

Although some research papers have already explored commercial ecosystems, SMEs, clusters, and keystones, Taiwan mainly focuses on SMEs, hoping that keystones can lead other companies. This paper will use the manufacturing and service industry as the sample population to explore the factors that influence the development of its strategy.

\subsection{Literature Review}

\subsubsection{Related Literature on Clustering}

According to Furman et al. [15], industrial clustering is conducive to industrial innovation. Enterprises within a cluster experience the same competitive pressures and market opportunities when they are under the same geographical environment. Under circumstances where information flow and human resources are moving fast, it will help promote the spillover effect within the industry and strengthen the advantages of industrial innovation.

Porter [6] believed that the formation of industrial clusters is due to the close ties between industries or firms, and the combination of vertical (buyer or supplier) and horizontal (common customers, technologies or pathways, etc.) perspectives. This guarantees that the interests will complement each other. Anderson [16] divided the interdependence among cluster companies into three parts: (1) upstream and downstream supply relationships; (2) cooperation and competition among peers; and (3) shared resources. Morgan [17] believed that the integration of clustering companies is not only due to their geographical location, but also because they share the same combination of ideas and vision, creating a tight bond between them.

Bell et al. [18] also pointed out that the formation of a cluster network contributes to the improvement of competitiveness. They explained that the clustering phenomenon is the main knowledge-driven catalyst based on the perspective of regional economy and modern management theory. Through trust, dependence, interaction, competition, etc., and the interactions within the network structure, cooperation patterns, and cooperation interests, a competitive edge is created.

Rosenfeld [19] believed that manufacturers are concentrated in space. Even if the scale of the employees in the company is not significant and prominent, they will still produce complementary effects because of the proximity in space and mutual dependence. Roelandt et al. [20] believed that clustering can be described as a network of producers where interdependent manufacturers are strongly linked together in the value chain. Crouch 
and Farrell [21] defined clustering as companies with the same corporate form still being closely located together even in the absence of an important event in space.

Feser and Bergman [22] combined the two ideas stated above and further defined clustering as a combination of formal input-output relations, a buyer-seller combination, geographical concentration, industry-related organizations, and a combination of "competitive relations". Manufacturers in a specific cluster do not only share their resources, but also generate industrial synergy effect and flexible production efficiency through interaction and exchange.

Redman [23] defined clustering as a combination of single or similar product manufacturers, forming production chains through geological clustering. These kinds of production chain relations affect the entire industry's level of competition. Manufacturers choose to join a specific cluster based on mutual dependence in order to increase economic activity, promote mutual business transactions, and produce synergy [19]. Rosenfeld [19] extended the former definition of industrial clustering, and provided the following features: first, it is an open system that allows members to join or withdraw freely, making it less restrictive for its members; second, it utilizes reciprocity, which provides incentives for manufacturers, stimulates demand from manufacturers, and attracts manufacturers to join in; third, it uses a cooperative and competitive operation mode; and lastly, it establishes a common vision among the members and outlines the future development blueprint for them.

Enright [24] believed that industrial clusters are different from enterprise networks and regional clusters. Industrial clusters are described as a group of related companies established through interactions among existing vendors and suppliers having common technology, vendors, and labor supply sources. In an enterprise network, although manufacturers engage in interactions and exchanges, they are not limited to the related or same leading manufacturers, nor are they necessarily geographically connected. Meanwhile, a regional cluster is an industrial cluster; although manufacturers are concentrated in a region, they belong in an elastic cross-regional network, and consist of both suppliers contributing at different stages of the value chain and finished product manufacturers, forming an agglomerating effect in a decentralized production manner. This type of regional clustering is best represented by the Italian fashion industry. The effect of a regional cluster created today's status of Milan as the fashion industry capital.

Rabellotti [25] pointed out that clusters mainly consist of four major components: (1) spatially aggregated firms of similar types; (2) regional economic behaviors created by society and culture; (3) vertical and horizontal interactions based on the exchange of market and non-market goods, services, information, and talent; and (4) the government and a local private network of agencies providing the necessary support for enterprises. Finally, Markusen [26] provided the four main types of clustering, which are: (1) Marshallian clustering, which focuses on cooperation among regional manufactures; (2) keystone clustering, wherein one or more manufacturers are leading in the cluster, and where manufacturers are connected by the cohesiveness of the clustering vendors; (3) satellite clustering, which has a lower frequency of cluster interactions, and has more interactions outside of the clusters; and (4) government-led clustering, which is dominated by large institutions established or supported by the government.

Regarding the type of clustering, Wang [27] integrated his study to that of Chen [28], and proposed that, when considering the factors of government resource allocation and policy level, the industrial clusters should be classified according to their characteristics, purposes, and driving factors. In terms of traits, he stated that three directions must be considered: (1) regional or trans-regional, (2) emerging or existing, and (3) high-tech or soft technology. Clustering can also be classified into organizational compound clustering, service innovation clustering, technology-based niche clustering, in situ innovation clustering, mature network clustering, value network clustering, emerging technology clustering, and innovative network clustering. Various types have their own definitions and traits. For example, in the case of organizational compound clustering, its characteristics are geographical concentration, mature clustering, and high-tech drive. 
Jia and Cai [29] stated that the cluster development stage involves the formation, development, maturity, and transformation of enterprise clusters. Cluster formation is similar to the nature of the business ecosystem. This study utilizes the SMEs' e-clustering counseling proposal and operation specification under the SME Digital Care Program [30], which involves four stages: (1) agglomeration period, (2) active period, (3) integration period, and (4) perpetual period.

\subsubsection{Related Literature on Business Ecology}

Li [31] proposed that the business ecosystem goes beyond market positioning and corporate organization, and provided three main characteristics: (1) symbiosis, (2) platform, and (3) co-evolution. Aside from these, some scholars proposed three other characteristics of the business ecosystem: (1) loose networks, (2) platforms, and (3) core products of complementary assets. The first characteristic refers to the loose network present in the business ecosystem, consisting of suppliers, distributors, outsourcing companies, manufacturers, technology providers, and many other organization owners of related products or services that are affected by the company's own contribution and creation. Moore [32] believed that Apple, IBM, Ford Motor, and Wal-Mart, all leaders in the business-state system, value all of the clusters in the entire ecosystem. These leaders are able to make all members work hard toward the future of a common investment. The second characteristic, platform, includes services, tools, and technologies that can all be used by business ecosystem members to enhance their own performance. Lastly, the third characteristic involves the development of the business ecosystem to bring its participants to a new realm. The business eco-environment aims to bring a wide range of technical standards with the added value of social enterprises and individuals by providing core products for complementary assets; for example, Apple's core product, the iPod, and its peripheral products, are not manufactured by Apple Computer [11,31,32].

Moore [32] proposed the business ecosystem life cycle, which divides the life of the business ecosystem into four phases: (1) birth, (2) expansion, (3) guidance, and (4) selfrenewal or death. The issues being faced by managers at each stage are not the same; the only ones that remain unchanged are the interactive influences of companies competing and collaborating, and the complex strategies used. Further, according to his studies, companies encounter different challenges during competition and cooperation at each stage of the life cycle; therefore, different managerial actions should be implemented to defend the established business ecosystem. Moore [33] has expanded his previous research and provided firms with different suggestions based on the four phases of the business ecosystem's life cycle. It included recommendations for keystone species that play a leading role in the ecosystem, focusing on how to collaborate with other ethnic groups in their dominant ecosystems and prevent them from tying with others, and how to ensure that their established ecosystems can be maintained for long periods and will not be replaced by other ecosystems. Although it was mentioned that keystone species play a primary role in the ecosystem, their relationship with other species was not elaborated.

Gossain and Kandiah [34] quoted Moore [32,33] on the concept of the business ecosystem and discussed the importance of the internet in today's information economy. Power and Jerjian [35] defined a business ecosystem as a network that spreads around the world and interacts with the virtual reality world. Peltonemi and Vuori [36] believed that business ecosystems must self-emerge, self-organize, and co-evolve, and should have the ability to adapt to an industrial environment. The commercial ecosystems work together and compete at the same time, constantly changing their complex compositions to adapt to the entire system and generate new insights.

Iansiti and Levien [10] also supported Moore's basic ideas and used other ecosystems as an analogy for the business ecosystem. They defined the business ecosystem as being composed of a group of loosely linked, yet destined, systemic participants, co-evolving with each other, and creating and sharing values. In addition, to be able to discuss the strategic choices of system participants in the face of a system environment, participants 
in the ecosystem were categorized based on whether they possess core technologies or control the operational order; they are classified into: (1) keystones, (2) physical dominators, (3) hub landlords, and (4) niche players [11].

\subsubsection{Related Literature on Keystone Enterprise}

Iansiti and Levien [11] believed that keystone-type companies can ensure their own survival and prosperity by constantly improving the fitness and productivity of their ecosystems, strengthening their stability, or creating new niches in their networks, and therefore consolidating their position. A dysfunctional keystone-type company may harm the health of the entire ecosystem and even endanger themselves and other members of the system. If one keystone-type company is suddenly pulled out from the entire business ecosystem, a series of dramatic and chaotic restructurings may follow.

The practice of most keystone-type companies is to first create a platform, such as a service, tool, or technology, which will serve as the company's asset. This asset can either be a physical platform or a knowledge platform that provides solutions to other members of the ecosystem. Keystone-type companies will then share most of the value created by the platform with their network partners [10]. Furthermore, keystone-type companies will often share their value with other partners in the ecosystem while creating value for themselves [37]. The revenue, manpower, and market value of keystone-type companies often account for only a small part of the overall ecosystem; however, they obtain huge effects by using their advantages in cyberspace. In the business ecosystem, the interactions among companies are multi-faceted and are shown at multilevel. Groups, enterprises, technology, and products interact in a complex network of business ecosystems; the interaction at one level often affects other levels [38].

It can be found that niche players interact with the keystones; the latter provide resources, including technology, partners, reputation, and knowledge [39]. Niche players utilize these resources in different methods. First, the "technology" of the keystones is used by niche players to develop various products; second, the "passengers" of the keystones are used to expand their customer base; third, the "reputation" of the keystones is utilized to increase the trust of channel providers and customers; lastly, the "knowledge" of the keystones are learned by niche players, including "technical knowledge" and "management knowledge". Takata [40] believes that the selection of platform strategies by leaders in the ecosystem can be based on the degree of openness of the platform and the openness of the internet, forming four strategic proposals.

Kim et al. [41] looked into knowledge-intensive and environmental turbulence perspectives, as well as den Hartigh et al. [42], considered on the phases of good partner health and internet. In a food network or other network where natural ecosystems interact, species that plays a central role in the face of volatile changes have the ability to increase their chances of survival by benefiting the natural ecosystem [43].

Core companies have a significant impact on the value creation and value distribution of the business ecosystem, and the creation and distribution of values determine the health of the business ecosystem; therefore, if it is overly concentrated on a small number of companies, there is a high chance that the business system will disintegrate. In response, Iansiti and Levien [11] proposed three major indicators to measure the integrity of the business ecosystem: (1) productivity, (2) robustness, and (3) niche creation. Productivity is a basic factor; most industries use it to determine the success of the company. Stability is another important factor to consider for any business ecosystem. Under the natural development of the business ecosystem, the degree of robustness indicates the ability of the system to survive when an internal or external turmoil or threat is present. In the business environment, robustness also entails the ability to transform multiple sources into competitive advantages under changes in the environment. Consequently, a business ecosystem should have the ability to create niches and opportunities for new companies.

Productivity refers to the efficacy and efficiency of transforming raw material into products as the output ratio per capital [44]. Robustness means offering endurable benefits 
for dependent creatures in the ecosystem who are faced with challenges and changes from the external environment. Similarly, if the business ecosystem can avoid corruption when consumers encounter new technologies without expectation, the profits become obvious. When a company is incorporated into a predictable and complete business ecosystem and is in a good relationship with others, it could withstand impacts from the external environment.

Robustness in biology denotes the tendency of a system to maintain its characteristic behaviors in turbulent or uncertain situations [45]. Low-level robustness suggests that a hypothesis of a small amplitude may not be easy to verify when the turbulence amplitude is small, as the variance depends on actual issues. In contrast, the robustness of big issues means that hypotheses cannot be made in the amplitude of turbulence, as the turbulence can be either big or small [46]. Robustness can be categorized into two dimensions: the ability to resist and the ability to avoid change [47].

Niche creation arises from the fact that productivity and robustness cannot obtain all of the characteristics of a complete business ecosystem. According to the literature on ecology, the diversity of ecosystems also counts as a way to support the diversity of species. It is the same for the business ecosystem. Business ecosystems have to be capable of absorbing external impacts and potential productivity reforms $[10,11]$. It is important to improve the ecosystem's capacity to increase meaningful diversity through the creation of valuable new functions or niches.

This requires a transformative way of thinking to make everything work for the betterment of the company. Furthermore, each indicator is composed of several related factors, which are described in the following:

1. Productivity

(a) Factors of productivity: analysis of the ability of the members of a business ecosystem to convert productivity into products, such as the overall capital return rate of the industry;

(b) Changes in productivity: understanding the trends in the factors of productivity over a period of time, such as trends in return on capital employed;

(c) Delivery of innovation: examines whether new technologies can be quickly and effectively communicated among members of the business ecosystem, such as the adoption of new technologies.

2. Robustness

(a) Survival rate: demonstrates whether the members of the ecosystem have a greater chance to survive compared with other ecosystems;

(b) Durability of the ecosystem structure: illustrates whether the structure of the ecosystem can withstand changes from the external environment;

(c) Predictability: the extent to which the changes in the ecosystem can be predicted and controlled;

(d) Continuity of using experience and case: as consumers face a new technology, the experience they undergo is usually gradual, rather than drastic and substantial.

3. Niche Creation

(a) Diversity of manufacturers: demonstrates the changes in the types of new companies within a certain period of time;

(b) Diversity of products and technologies: demonstrates the changes in the number of newly created products or technologies within a certain period of time.

According to Iansiti and Levien [11], a business ecosystem can be divided into a number of small business sub-ecosystems or several domains. All participants of the small sub-systems are niche players as opposed to the dominators of the whole business ecosystem. However, sometimes sub-systems may have their own dominators, who play a key leading role in contrast to other participants. When it comes to the whole software 
business ecosystem, those dominators of sub-systems are still niche players with close connections to keystones. In other words, most manufacturers can join in multiple business ecosystems and play different roles in different sub-systems, as later suggested by Iyer et al. [48].

Dedehayir et al. [49] proposed that new technologies, mutual cooperation, and cocreation can promote productivity and competitiveness. Choi et al. [50] evaluated the IOT (Internet of Things) ecosystem by employing seven factors using the three aspects of robustness, productivity, and diversity. Kannangara and Uguccioni [51] achieved maximum robustness by lowering the risks of the business ecosystem via crowdsourcing. Lappi et al. [52] believed that sustainability, adaptability, innovation, and steadiness are keys to maintaining the level of health of ecosystems. Vargo et al. [53] suggested that process innovation is driven by the integration, exchange, and resource application of different members.

The sub-factors and explanations of the keystone business strategy are shown in Tables 1 and 2.

Table 1. Factors that influence keystone business strategy.

\begin{tabular}{|c|c|c|}
\hline Factor & Sub-Factors & Bibliography \\
\hline \multirow{4}{*}{ Platform Operation } & Technology & $\begin{array}{c}\text { Iansiti and Levien [10], Takata [40], Kuo et al. [39], } \\
\text { Paine [43], den Hartigh et al. [42] }\end{array}$ \\
\hline & Partner & Adner and Kapoor [38], Anthony Kuo et al. [39] \\
\hline & Reputation & Kuo [3], Lo [3] \\
\hline & Knowledge & Iansiti and Levien [10], Kuo et al. [39], Kim et al. [41] \\
\hline \multirow{3}{*}{ Productivity } & Factors of Productivity & \multirow{3}{*}{$\begin{array}{l}\text { Iansiti and Levien [10], Pierce [44], Dedehayir et al. } \\
\text { [49], Choi et al. [50] }\end{array}$} \\
\hline & Changes in Productivity & \\
\hline & Delivery of Innovation & \\
\hline \multirow{4}{*}{ Robustness } & Survival Rate & \multirow{4}{*}{$\begin{array}{c}\text { Iansiti and Levien [10], Wieland and Wallenburg } \\
\text { [45], Alippi [46], Durach et al. [47], Kannangara and } \\
\text { Uguccioni [51], Lappi et al. [52] }\end{array}$} \\
\hline & Durability of the Ecosystem Structure & \\
\hline & Predictability & \\
\hline & Continuity of Using Experience and Case & \\
\hline \multirow{2}{*}{ Niche Creation } & Diversity of Manufacturers & \multirow{2}{*}{$\begin{array}{l}\text { Iansiti and Levien [10], Iyer et al. [48], Kuo et al. [39], } \\
\text { Vargo et al. [53] }\end{array}$} \\
\hline & Diversity of Products and Technologies & \\
\hline
\end{tabular}

Table 2. Explanations on the keystone business strategy.

\begin{tabular}{|c|c|c|}
\hline Factors & Sub-Factors & Explanations \\
\hline \multirow{4}{*}{ Platform Operation } & Technology & Use of "technology" of the keystones to develop various products. \\
\hline & Partners & Use of the "passengers" of the keystones to expand their customer base. \\
\hline & Reputation & $\begin{array}{l}\text { Use of the "reputation" of the keystones to increase the trust of channel } \\
\text { providers and customers. }\end{array}$ \\
\hline & Knowledge & $\begin{array}{c}\text { Use of the "knowledge" of the keystones, including "technical knowledge" } \\
\text { and "management knowledge". }\end{array}$ \\
\hline \multirow{3}{*}{ Productivity } & Factor of Productivity & $\begin{array}{l}\text { Analysis of the ability of the members of the ecosystem to convert productivity } \\
\text { into products, such as the overall capital return rate of the industry. }\end{array}$ \\
\hline & $\begin{array}{l}\text { Changes in } \\
\text { Productivity }\end{array}$ & $\begin{array}{l}\text { Understanding the trends in the factors of productivity over a certain period of } \\
\text { time, such as trends in the return of capital employed. }\end{array}$ \\
\hline & Delivery of Innovation & $\begin{array}{l}\text { Demonstrates whether new technologies can be quickly and effectively } \\
\text { communicated among members of the business ecosystem, such as the } \\
\text { adoption of new technologies. }\end{array}$ \\
\hline
\end{tabular}


Table 2. Cont.

\begin{tabular}{|c|c|c|}
\hline Factors & Sub-Factors & Explanations \\
\hline \multirow{4}{*}{ Robustness } & Survival Rate & $\begin{array}{c}\text { Demonstrates whether the members of the ecosystem have a greater chance to } \\
\text { survive compared with other ecosystems }\end{array}$ \\
\hline & $\begin{array}{l}\text { Durability of the } \\
\text { Ecosystem Structure }\end{array}$ & $\begin{array}{c}\text { Demonstrates whether the structure of the ecosystem can withstand changes } \\
\text { from the external environment }\end{array}$ \\
\hline & Predictability & $\begin{array}{c}\text { Indicates the extent to which the changes in the ecosystem can be predicted } \\
\text { and controlled }\end{array}$ \\
\hline & $\begin{array}{l}\text { Continuity of Using } \\
\text { Experience and Case }\end{array}$ & $\begin{array}{l}\text { As consumers face a new technology, the experience they undergo is usually } \\
\text { gradual rather than drastic and substantial. }\end{array}$ \\
\hline \multirow{2}{*}{ Niche Creation } & $\begin{array}{l}\text { Diversity of } \\
\text { Manufacturers }\end{array}$ & Indicates the changes in the types of new companies within a period of time \\
\hline & $\begin{array}{l}\text { Diversity of Products } \\
\text { and Technologies }\end{array}$ & $\begin{array}{c}\text { Indicates the changes in the number of newly created products or technologies } \\
\text { within a period of time }\end{array}$ \\
\hline
\end{tabular}

\section{Materials and Method}

This study used the FAHP method [54] supplemented by the collection and collation of internal document data to present the true situation in a systematic manner. In addition, this study conducted a semi-structured in-depth interview, and collected data to echo the theory underlying the research.

Each case of manufacturing cluster was analyzed based on the type of clustering, the development stage of clustering, and the degree of application of keystone strategies. Figure 1 shows the architecture of the FAHP mode for assessing the factors that impact keystone-type business strategies (Tables 3 and 4).

Table 3. The cluster development life cycle.

\begin{tabular}{|c|c|}
\hline Life Cycle & Explanations \\
\hline Agglomeration Phase & $\begin{array}{l}\text { The purpose is to establish the agglomeration force, emphasizing integration degree, collective } \\
\text { learning, and cluster collaboration platform networks. }\end{array}$ \\
\hline Active Phase & $\begin{array}{c}\text { The purpose is to establish the active force, emphasizing the marketing ability of cluster collaboration } \\
\text { platform networks. }\end{array}$ \\
\hline Integration Phase & $\begin{array}{l}\text { The purpose is to establish the integration force by both hosting large-scale exhibitions and sales and } \\
\text { network activities based on local government resources and establishing a stable marketing model } \\
\text { and cluster revenue mechanism. }\end{array}$ \\
\hline Perpetual Phase & $\begin{array}{l}\text { The purpose is to establish the perpetual force by establishing the brand and mature operating } \\
\text { mechanism using multiple channels. }\end{array}$ \\
\hline
\end{tabular}

Table 4. The role of a business ecosystem.

\begin{tabular}{cc}
\hline Role & Explanations \\
\hline Key Stone & $\begin{array}{r}\text { The health regulators of the business ecosystem are richly connected hubs with core technologies, and can play a } \\
\text { critical role in the vibrant and changing environment. With their professional knowledge, experience, technology, } \\
\text { tools, or status, they can effectively connect the human, material, or social resources to create a mutually beneficial } \\
\text { and symbiotic cooperation platform or provide altruistic assistance to other ecosystem members. }\end{array}$ \\
\hline Dominator & $\begin{array}{r}\text { Species with core technologies or regulators in the whole business ecosystem can provide a platform for other system } \\
\text { participants to create a value, such as a keystone. }\end{array}$ \\
Niche Player & $\begin{array}{r}\text { The largest species in the ecosystem can use the platform and resources provided by key species (e.g., keystones) to } \\
\text { develop a SMEs business when facing a turbulent and changing environment. It can form development characteristics } \\
\text { and expertise that are different from others to create a unique value. }\end{array}$ \\
\hline Hub Landlord & $\begin{array}{r}\text { They used to be a species with core technologies or regulating power in the ecosystem, which only focused on seizing } \\
\text { business value rather than creating their value. In other words, they mistook their influence and grabbed too much } \\
\text { value without properly sharing the value with other participants. }\end{array}$ \\
\hline
\end{tabular}


FAHP Structure

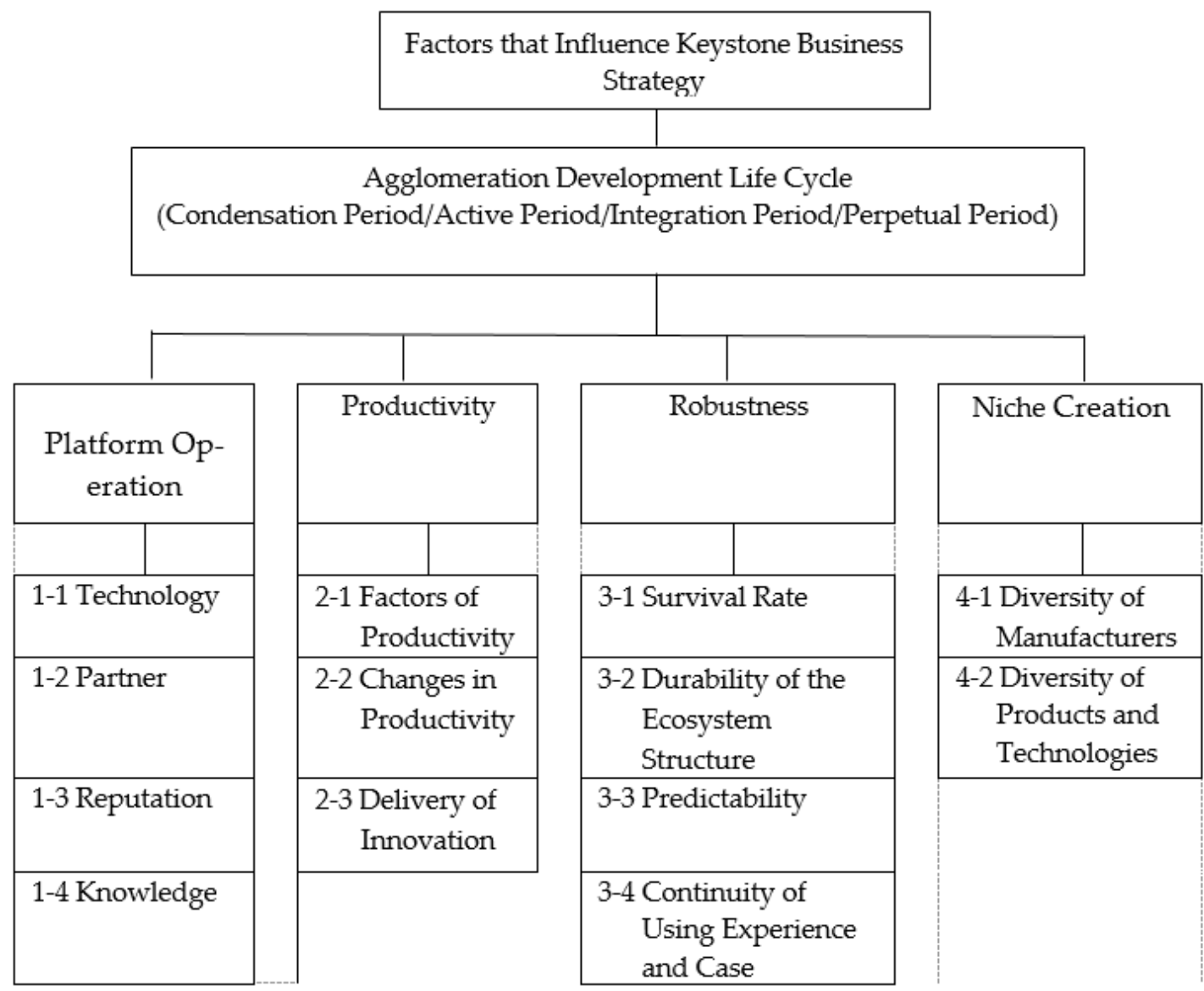

Figure 1. Assessment criteria for the factors that impact keystone-type business operation strategy.

\section{Results}

\section{Research Samples}

This study used FAHP to construct an assessment scale of the factors that influence a keystone-type business strategy; therefore, the questionnaire used the FAHP to compare the evaluation surface with each of the evaluation criteria, and assessed the evaluation weight of each aspect and each criterion. This study divided the questionnaire into five major parts, which are shown in Appendix A. The first part describes the structure of the questionnaire; the second part provides a description of the study's research factors and evaluation criteria, and is divided into four major aspects and thirteen assessment criteria (Tables 2-4); the third part describes the FAHP questionnaire and the method for answering it, which compares the evaluation factors and assessment criteria with the nominal scale. It includes: absolutely important, extremely important, important, slightly important, and equally important. Measurement values are from 1 to 9; with numbers 9, 7, 5, 3, and 1 assigned to the nominal scale. The fourth part includes the contents of the FAHP questionnaire. The respondents are asked to grade the level of importance of each evaluation factor and criteria. Lastly, the fifth part allows the respondent to fill in basic background information.

Based on related literature and research institutes, the number of experts to be interviewed should be between five to fifteen individuals [55]; therefore, this study invited 15 experts in keystone-type business strategies. A total of eight out of ten collected questionnaires were considered valid. The data and background of the valid questionnaires collected are shown in Table 3. Moreover, 15 experts in the service industry were invited in this study to answer the questionnaire. A total of seven out of eight collected questionnaires 
were considered valid. The data and background of the valid questionnaires collected are shown in Table 4.

This study developed an evaluation scale for the factors that influence keystone-type business strategies through a literature review and pre-test expert questionnaire interviews. The keystone-type business strategy was assessed based on the four aspects of a business ecosystem (platform operations, productivity, robustness, and niche creation), including their related factors, creating thirteen assessment criteria for pairwise comparison. This was carried out for each cluster development life cycle, namely: agglomeration period, active period, integration period, and perpetual period. The FAHP method was utilized to analyze and aggregate the opinions of the six experts. This eventually resulted in the weight values of the keystone-type business strategy factors and criteria. The results are shown in Tables 5-14.

Table 5. List of interviewed experts.

\begin{tabular}{cccc}
\hline Expert Code & Type of Industry & Position & Years of Experience \\
\hline Expert 1 & Manufacturing & Project Manager & 7 \\
\hline Expert 2 & Manufacturing & Specialist & 5 \\
\hline Expert 3 & Manufacturing & General Manager & 10 \\
\hline Expert 4 & Manufacturing & Project Manager & 5 \\
\hline Expert 5 & Manufacturing & General Manager & 20 \\
\hline Expert 6 & Manufacturing & Engineer & 23 \\
\hline Expert 7 & Manufacturing & Manager & 20 \\
\hline Expert 8 & Manufacturing & Deputy Engineer & 5 \\
\hline
\end{tabular}

Table 6. List of interviewed experts.

\begin{tabular}{cccc}
\hline Expert Code & Type of Industry & Position & Years of Experience \\
\hline Expert 1 & Service & General Manager & 2 \\
\hline Expert 2 & Service & Senior Analyst & 21 \\
\hline Expert 3 & Service & Planner & 13 \\
\hline Expert 4 & Service & Team Leader & 20 \\
\hline Expert 5 & Service & Deputy Manager & 22 \\
\hline Expert 6 & Service & Business Planner & 5 \\
\hline Expert 7 & Service & General Manager & 10 \\
\hline
\end{tabular}


Table 7. Weight values of the keystone-type business strategy factors and criteria in agglomeration period.

\begin{tabular}{|c|c|c|c|c|c|c|c|}
\hline Factors & Normalization Weights & Sorting & Sub-factors & Normalization Weights & Intra-Group Weight Sorting & Level Concatenation Weights & Overall Sorting \\
\hline \multirow{3}{*}{ Platform Operation (A1) } & \multirow{3}{*}{0.4313} & \multirow{3}{*}{1} & Technology (A1.1) & 0.2791 & 2 & 0.1204 & 2 \\
\hline & & & Partner (A1.2) & 0.2607 & 3 & 0.1125 & 5 \\
\hline & & & Reputation (A1.3) & 0.2815 & 1 & 0.1214 & 2 \\
\hline \multirow{3}{*}{ Productivity(A2) } & \multirow{3}{*}{0.1176} & \multirow{3}{*}{4} & Element Productivity (A2.1) & 0.3401 & 2 & 0.0400 & 9 \\
\hline & & & Productivity Changes (A2.2) & 0.2340 & 3 & 0.0275 & 13 \\
\hline & & & Innovative Delivery (A2.3) & 0.4259 & 1 & 0.0501 & 8 \\
\hline \multirow{4}{*}{ Robustness (A3) } & \multirow{4}{*}{0.1982} & \multirow{4}{*}{3} & Survival Rate (A3.1) & 0.4714 & 1 & 0.0940 & 6 \\
\hline & & & Ecosystem Structure Durability (A3.2) & 0.1901 & 2 & 0.0378 & 10 \\
\hline & & & Predictability (A3.3) & 0.1701 & 3 & 0.0337 & 11 \\
\hline & & & Experience and Case Continuity (A3.4) & 0.1650 & 4 & 0.0327 & 12 \\
\hline \multirow{2}{*}{ Niche Creation (A4) } & \multirow{2}{*}{0.2528} & \multirow[b]{2}{*}{2} & Manufacturer Diversity (A4.1) & 0.5367 & 1 & 0.1357 & 1 \\
\hline & & & Product and Technology Diversity (A4.2) & 0.4633 & 2 & 0.1171 & 4 \\
\hline
\end{tabular}

Table 8. Weight values of keystone-type business strategy factors and criteria in active period.

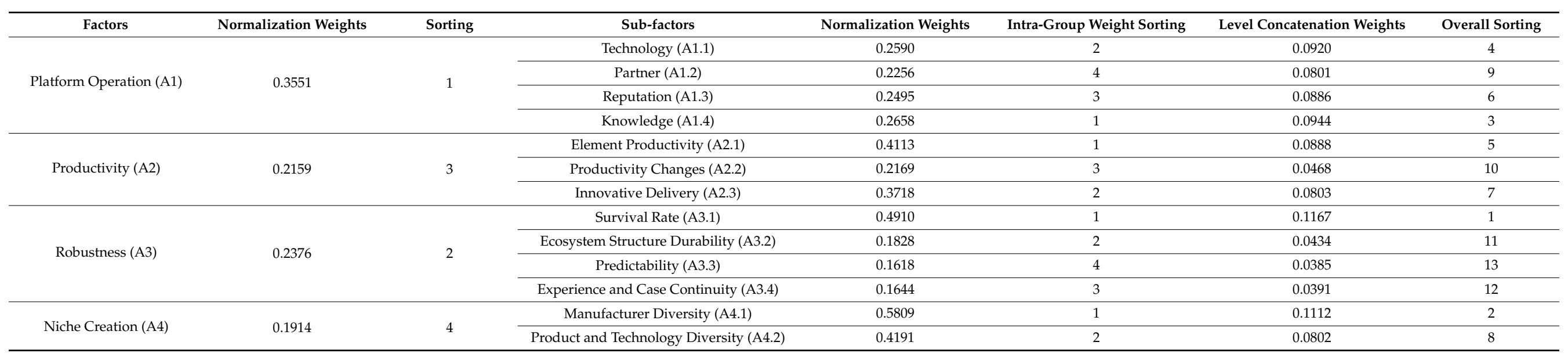


Table 9. Weight values of the keystone-type business strategy factors and criteria in integration period.

\begin{tabular}{|c|c|c|c|c|c|c|c|}
\hline Factors & Normalization Weights & Sorting & Sub-factors & Normalization Weights & Intra-Group Weight Sorting & Level Concatenation Weights & Overall Sorting \\
\hline \multirow{3}{*}{ Platform Operation (A1) } & \multirow{3}{*}{0.3660} & \multirow{3}{*}{1} & Technology (A1.1) & 0.3135 & 1 & 0.1148 & 1 \\
\hline & & & Partner (A1.2) & 0.2710 & 2 & 0.0992 & 3 \\
\hline & & & Reputation (A1.3) & 0.2224 & 3 & 0.0814 & 7 \\
\hline \multirow{3}{*}{ Productivity (A2) } & \multirow{3}{*}{0.2421} & \multirow{3}{*}{2} & Element Productivity (A2.1) & 0.3844 & 2 & 0.0930 & 6 \\
\hline & & & Productivity Changes (A2.2) & 0.2136 & 3 & 0.0517 & 10 \\
\hline & & & Innovative Delivery (A2.3) & 0.4021 & 1 & 0.0973 & 4 \\
\hline \multirow{4}{*}{ Robustness (A3) } & \multirow{4}{*}{0.1982} & \multirow{4}{*}{3} & Survival Rate (A3.1) & 0.3455 & 1 & 0.0685 & 9 \\
\hline & & & Ecosystem Structure Durability (A3.2) & 0.2188 & 3 & 0.0434 & 12 \\
\hline & & & Predictability (A3.3) & 0.1787 & 4 & 0.0354 & 13 \\
\hline & & & Experience and Case Continuity (A3.4) & 0.2570 & 2 & 0.0509 & 11 \\
\hline \multirow{2}{*}{ Niche Creation (A4) } & \multirow{2}{*}{0.1937} & \multirow{2}{*}{4} & Manufacturer Diversity (A4.1) & 0.5219 & 1 & 0.1034 & 2 \\
\hline & & & Product and Technology Diversity (A4.2) & 0.4781 & 2 & 0.0948 & 5 \\
\hline
\end{tabular}

Table 10. Weight values of the keystone-type business strategy factors and criteria in perpetual period.

\begin{tabular}{|c|c|c|c|c|c|c|c|}
\hline Factors & Normalization Weights & Sorting & Sub-factors & Normalization Weights & Intra-Group Weight Sorting & Level Concatenation Weights & Overall Sorting \\
\hline \multirow{4}{*}{ Platform Operation (A1) } & \multirow{4}{*}{0.2361} & \multirow{4}{*}{3} & Technology (A1.1) & 0.2947 & 1 & 0.0696 & 5 \\
\hline & & & Partner (A1.2) & 0.1990 & 4 & 0.0470 & 11 \\
\hline & & & Reputation (A1.3) & 0.2922 & 2 & 0.0690 & 6 \\
\hline & & & Knowledge (A1.4) & 0.2141 & 3 & 0.0505 & 10 \\
\hline \multirow{3}{*}{ Productivity (A2) } & \multirow{3}{*}{0.1417} & \multirow{3}{*}{4} & Element Productivity (A2.1) & 0.3866 & 1 & 0.0548 & 9 \\
\hline & & & Productivity Changes (A2.2) & 0.2854 & 3 & 0.0404 & 13 \\
\hline & & & Innovative Delivery (A2.3) & 0.3280 & 2 & 0.0465 & 12 \\
\hline \multirow{3}{*}{ Robustness (A3) } & \multirow{3}{*}{0.3024} & \multirow{3}{*}{2} & Survival Rate (A3.1) & 0.2306 & 2 & 0.0697 & 4 \\
\hline & & & Predictability (A3.3) & 0.2048 & 4 & 0.0619 & 8 \\
\hline & & & Experience and Case Continuity (A3.4) & 0.3514 & 1 & 0.1063 & 3 \\
\hline \multirow{2}{*}{ Niche Creation (A4) } & \multirow{2}{*}{0.3199} & \multirow{2}{*}{1} & Manufacturer Diversity (A4.1) & 0.5173 & 1 & 0.1655 & 1 \\
\hline & & & Product and Technology Diversity (A4.2) & 0.4827 & 2 & 0.1544 & 2 \\
\hline
\end{tabular}


Table 11. Weight values of the keystone-type business strategy factors and criteria in agglomeration period of service industry.

\begin{tabular}{|c|c|c|c|c|c|c|c|}
\hline Factors & Normalization Weights & Sorting & Sub-factors & Normalization Weights & Intra-Group Weight Scoring & Level of Concatenation Weights & Overall Sorting \\
\hline \multirow{3}{*}{ Platform Operation (A1) } & \multirow{3}{*}{0.5022} & \multirow{3}{*}{1} & Technology (A1.1) & 0.2349 & 4 & 0.1187 & 5 \\
\hline & & & Partner (A1.2) & 0.2554 & 1 & 0.1290 & 2 \\
\hline & & & Reputation (A1.3) & 0.2544 & 3 & 0.1285 & 4 \\
\hline \multirow{3}{*}{ Productivity (A2) } & \multirow{3}{*}{0.1124} & \multirow{3}{*}{4} & Element Productivity (A2.1) & 0.4613 & 1 & 0.0519 & 9 \\
\hline & & & Productivity Changes (A2.2) & 0.1805 & 3 & 0.0203 & 13 \\
\hline & & & Innovative Delivery (A2.3) & 0.3583 & 2 & 0.0403 & 10 \\
\hline \multirow{4}{*}{ Robustness (A3) } & \multirow{4}{*}{0.1666} & \multirow{4}{*}{3} & Survival Rate (A3.1) & 0.3236 & 1 & 0.0539 & 7 \\
\hline & & & Ecosystem Structure Durability (A3.2) & 0.3117 & 2 & 0.0519 & 8 \\
\hline & & & Predictability (A3.3) & 0.1811 & 4 & 0.0302 & 12 \\
\hline & & & Experience and Case Continuity (A3.4) & 0.1836 & 3 & 0.0328 & 11 \\
\hline \multirow{2}{*}{ Niche Creation (A4) } & \multirow{2}{*}{0.2158} & \multirow{2}{*}{2} & Manufacture Delivery (A4.1) & 0.69340 & 1 & 0.14960 & 1 \\
\hline & & & Product and Technology Diversity (A4.2) & 0.30660 & 2 & 0.06610 & 6 \\
\hline
\end{tabular}

Table 12. Weight values of the keystone-type business strategy factors and criteria in active period of service industry.

\begin{tabular}{|c|c|c|c|c|c|c|c|}
\hline Factors & Normalization Weights & Sorting & Sub-factors & Normalization Weights & Intra-Group Weight Scoring & Level of Concatenation Weights & Overall Sorting \\
\hline \multirow{3}{*}{ Platform Operation (A1) } & \multirow{3}{*}{0.4283} & \multirow{3}{*}{1} & Technology (A1.1) & 0.2491 & 3 & 0.1058 & 3 \\
\hline & & & Partner (A1.2) & 0.2508 & 2 & 0.1074 & 2 \\
\hline & & & Reputation (A1.3) & 0.3059 & 1 & 0.1310 & 1 \\
\hline \multirow{3}{*}{ Productivity (A2) } & \multirow{3}{*}{0.2133} & \multirow{3}{*}{2} & Element Productivity (A2.1) & 0.2363 & 3 & 0.0504 & 10 \\
\hline & & & Productivity Changes (A2.2) & 0.2685 & 2 & 0.0573 & 8 \\
\hline & & & Innovative Delivery (A2.3) & 0.4951 & 1 & 0.1056 & 4 \\
\hline \multirow{3}{*}{ Robustness (A3) } & \multirow{3}{*}{0.1864} & \multirow{3}{*}{3} & Survival Rate (A3.1) & 0.2328 & 3 & 0.0434 & 12 \\
\hline & & & Predictability (A3.3) & 0.2191 & 4 & 0.0408 & 13 \\
\hline & & & Experience and Case Continuity (A3.4) & 0.2887 & 1 & 0.0538 & 9 \\
\hline \multirow{2}{*}{ Niche Creation (A4) } & \multirow{2}{*}{0.1720} & \multirow[b]{2}{*}{4} & Manufacture Delivery (A4.1) & 0.46490 & 2 & 0.08000 & 7 \\
\hline & & & Product and Technology Diversity (A4.2) & 0.53510 & 1 & 0.09200 & 5 \\
\hline
\end{tabular}


Table 13. Weight values of the keystone-type business strategy factors and criteria in integration period of service industry.

\begin{tabular}{|c|c|c|c|c|c|c|c|}
\hline Factors & Normalization Weights & Sorting & Sub-factors & Normalization Weights & Intra-Group Weight Scoring & Level of Concatenation Weights & Overall Sorting \\
\hline \multirow{4}{*}{ Platform Operation (A1) } & \multirow{4}{*}{0.3768} & \multirow{4}{*}{1} & Technology (A1.1) & 0.2769 & 2 & 0.1043 & 4 \\
\hline & & & Partner (A1.2) & 0.2020 & 3 & 0.0761 & 7 \\
\hline & & & Reputation (A1.3) & 0.1864 & 4 & 0.0702 & 8 \\
\hline & & & Knowledge (A1.4) & 0.3347 & 1 & 0.1261 & 1 \\
\hline \multirow{3}{*}{ Productivity (A2) } & \multirow{3}{*}{0.2009} & \multirow{3}{*}{3} & Element Productivity (A2.1) & 0.2378 & 3 & 0.0478 & 13 \\
\hline & & & Productivity Changes (A2.2) & 0.2536 & 2 & 0.0509 & 11 \\
\hline & & & Innovative Delivery (A2.3) & 0.5086 & 1 & 0.1022 & 5 \\
\hline \multirow{4}{*}{ Robustness (A3) } & \multirow{4}{*}{0.2448} & \multirow{4}{*}{2} & Survival Rate (A3.1) & 0.2190 & 3 & 0.0536 & 10 \\
\hline & & & Ecosystem Structure Durability (A3.2) & 0.3398 & 1 & 0.0832 & 6 \\
\hline & & & Predictability (A3.3) & 0.2427 & 2 & 0.0594 & 9 \\
\hline & & & Experience and Case Continuity (A3.4) & 0.1984 & 4 & 0.0486 & 12 \\
\hline \multirow{2}{*}{ Niche Creation (A4) } & \multirow{2}{*}{0.1775} & \multirow{2}{*}{4} & Manufacture Delivery (A4.1) & 0.49360 & 2 & 0.12080 & 3 \\
\hline & & & Product and Technology Diversity (A4.2) & 0.50640 & 1 & 0.12400 & 2 \\
\hline
\end{tabular}

Table 14. Weight values of the keystone-type business strategy factors and criteria in perpetual period of service industry.

\begin{tabular}{|c|c|c|c|c|c|c|c|}
\hline Factors & Normalization Weights & Sorting & Sub-factors & Normalization Weights & Intra-Group Weight Scoring & Level of Concatenation Weights & Overall Sorting \\
\hline \multirow{3}{*}{ Platform Operation (A1) } & \multirow{3}{*}{0.2349} & \multirow{3}{*}{3} & Technology (A1.1) & 0.2879 & 1 & 0.0676 & 9 \\
\hline & & & Partner (A1.2) & 0.2330 & 3 & 0.0547 & 8 \\
\hline & & & Reputation (A1.3) & 0.2642 & 2 & 0.0621 & 5 \\
\hline \multirow{3}{*}{ Productivity (A2) } & \multirow{3}{*}{0.1721} & \multirow{3}{*}{4} & Element Productivity (A2.1) & 0.2198 & 3 & 0.0378 & 13 \\
\hline & & & Productivity Changes (A2.2) & 0.3277 & 2 & 0.0564 & 7 \\
\hline & & & Innovative Delivery (A2.3) & 0.4525 & 1 & 0.0779 & 4 \\
\hline \multirow{3}{*}{ Robustness (A3) } & \multirow{3}{*}{0.2757} & \multirow{3}{*}{2} & Survival Rate (A3.1) & 0.3514 & 1 & 0.0969 & 6 \\
\hline & & & Predictability (A3.3) & 0.1819 & 3 & 0.0501 & 10 \\
\hline & & & Experience and Case Continuity (A3.4) & 0.1691 & 4 & 0.0466 & 12 \\
\hline \multirow{2}{*}{ Niche Creation (A4) } & \multirow{2}{*}{0.3172} & \multirow{2}{*}{1} & Manufacture Delivery (A4.1) & 0.44330 & 2 & 0.14060 & 2 \\
\hline & & & Product and Technology Diversity (A4.2) & 0.55670 & 1 & 0.17660 & 1 \\
\hline
\end{tabular}




\section{Discussion}

The evaluation framework of the keystone business strategy was divided using the four periods of the development life cycle. For the agglomeration period, the most important factor is the platform operations, followed by niche creation, robustness, and productivity. The most important evaluation criterion for the platform operation is reputation; for niche creation, robustness, and productivity, the most important evaluation criterion is the diversity of manufacturers, survival rate, and innovative delivery, respectively. Overall, the most influential factor in the agglomeration period is the diversity of manufacturers.

For the active period, the most important factor is also platform operations, followed by robustness, productivity, and niche creation. The most important evaluation criterion for the platform operation is knowledge; for robustness, productivity, and niche creation, the most important evaluation criterion is survival rate, element productivity, and manufacturer diversity, respectively. Overall, for the active period, the most influential factor is the survival rate.

For the integration period, the most important factor is still platform operations, followed by productivity, robustness, and niche creation; the most important evaluation criterion for platform operation is technology; for productivity, robustness, and niche creation, the most important evaluation criterion is innovative delivery, survival rate, and manufacturer diversity, respectively. Overall, for the integration period, the most influential factor is the technology.

For the perpetual period, the most important factor, unlike the first three periods, is niche creation, followed by robustness, platform operation, and productivity; the most important evaluation criterion for niche creation is manufacturer diversity. For robustness, platform operation, and productivity, the most important evaluation criterion is experience and case continuity, technology, and element productivity, respectively. Overall, for the perpetual period, the most influential factor is the manufacturer diversity.

The evaluation framework of the keystone-type business strategy in the service industry was separated into four factors of capabilities. For the agglomeration period, the most important factor was the platform operation, followed by niche creation, robustness, and productivity. The most important evaluation criterion for platform operation was the partner; for niche creation, robustness, and productivity, the most important was the diversity of manufacturers, survival rate, and element productivity, respectively. Overall, the most influential factor in the agglomeration period was the diversity of manufacturers.

For the active period, the most important factor was platform operation, followed by productivity, robustness, and niche creation. The most important evaluation criterion for platform operation was reputation; for productivity, robustness, and niche creation, the most important factor was innovative delivery, experience and case continuity, and product and technology diversity, respectively. Overall, for the active period, the most influential factor was the reputation.

For the integration period, the most important factor was platform operation, followed by robustness, productivity, and niche creation. The most important evaluation criterion for platform operation was knowledge; for robustness, productivity, and niche creation, the most important evaluation criterion was ecosystem structure durability, innovative delivery, and product and technology diversity, respectively. Overall, for the integration period, the most influential factor was knowledge.

For the perpetual period, the most important factor was niche creation, followed by robustness, platform operation, and productivity. The most important evaluation criterion for niche creation was manufacturer diversity; for robustness, platform operation, and productivity, the most important was survival rate, technology, and product and innovative delivery, respectively. Overall, for the perpetual period, the most influential factor was the product and technology diversity. 


\section{Conclusions}

\subsection{The Analysis of Keystone-Type Business Strategy between Manufacturing and} Service Industries

The analysis above shows that the keystone business strategy considers platform operation as the main factor in the periods of agglomeration, active, and integration in the cluster of the development life cycle. This indicates that platform operation is an important core. Meanwhile, niche creation was observed to be the most influential factor in the perpetual period. This indicates that companies need to transform in order to survive.

The most important sub-factor in platform operation in the agglomeration period is reputation, indicating that it needs to build trust; active period is knowledge, indicating that it needs to expand the scope; and perpetual and integration periods are technology, indicating that it needs to expand the scope. The most important sub-factor in productivity in the agglomeration and integration periods is innovative delivery, which indicates that the rapid and effective dissemination of new technology should also be given importance. In the perpetual and integration, the element productivity is an important sub-factor, indicating that the conversion of production factors to products or services should be given important consideration. For robustness, survival rate is observed to be the most important sub-factor in the agglomeration, active, and perpetual period, indicating that the ability of a company to persist is the most important factor during these periods, and for the integration periods, the most important factors are experience and case continuity, indicating that the many cases are the most important. For niche creation, the diversity of manufacturers is the most important sub-factor in agglomeration, active, perpetual, and integration periods, indicating that companies need to have different synergies with various types of manufacturers.

Meanwhile, the keystone business strategy within the life cycle in the agglomeration and perpetual periods considers manufacturer diversity as the most important influencing sub-factor, which indicates that it needs different types of companies to generate the synergy. The most important sub-factor in the active period is survival rate, which indicates that its market has matured, and requires new products and technologies to increase its competitiveness. The most important sub-factor in the integration period is technology, which indicates that its market has matured, and requires technologies to increase its competitiveness (as shown in Table 13).

The keystone business strategy of the service industry considered platform operation as the major factor during the agglomeration, active, and perpetual periods in the clusters of the development life cycle. This indicates that platform operation is an important core. Meanwhile, niche creation was viewed as the most influential factor in the perpetual period, which means that companies need to seek transformation in order to survive.

For the keystone business strategy, the most important sub-factor in the platform operation in the agglomeration period was the partner, which suggests that it requires many friends to work together. For the active period, the most important sub-factor was reputation, indicating that it needs to build trust; and for the integration period, the most essential sub-factor was technology, indicating that it is the core. The most significant sub-factor in productivity in the agglomeration period was element productivity, which indicates that the conversion of production factors to products or services should be given important consideration. In the active, integration, and perpetual periods, innovative delivery was an important sub-factor; this means that the rapid and efficient dissemination of new technology should also be given significance. For robustness, ecosystem structure durability was the most critical sub-factor in the agglomeration, perpetual, and active periods, suggesting the value of one's ability to withstand changes from the external environment. For the integration period, the most important sub-factors were experience and case continuity, indicating that consumer experience is vital in the face of new technologies. For niche creation, manufacturer diversity was viewed as the most important sub-factor in the agglomeration period, implying that companies need to have different synergies with various types of manufacturers. For the active, integration, and perpetual periods, the 
product and technology diversity was the most significant sub-factor, indicating that they require changes in newly created products or technologies.

Meanwhile, the keystone business strategy within the life cycle in the agglomeration period viewed manufacturer diversity as the most significant influential sub-factor, which implies that it requires the cooperation of different companies. The most important subfactor in the active period was reputation, whereas knowledge was the most significant sub-factor in the integration period, indicating that the market has matured, and requires new products and technologies to increase its competitiveness. In the perpetual period, product and technology diversity was the most essential, suggesting the necessity of changes in the number of newly created products or technologies (see Table 14).

\subsection{The Comparison of Keystone-Type Business Strategy between Manufacturing and Service Industries}

As shown in Tables 15 and 16, the rankings of the factors within the agglomeration period in the cluster of the development life cycle were the same for both the manufacturing and service industries, with platform operation as its main factor and core. For the active period, only the rankings of productivity and robustness were different, which means that the manufacturing industry emphasizes robustness, whereas the service industry emphasizes productivity. For the integration period, the rankings of productivity and robustness were different from each other. However, the manufacturing industry focuses on productivity, whereas the service industry focuses on robustness. For the perpetual period, the rankings of factors were the same for both industries, with niche creation as the main factor, which indicates that transformation is required for sustained survival.

The keystone business strategy in the agglomeration period within the life cycle considered reputation as the most significant factor in the manufacturing industry, due to the demand of building trust at the beginning. Meanwhile, the service industry viewed element productivity as the most vital, since it requires the conversion of productivity into products or services. In the manufacturing industry, the most important evaluation criterion for productivity was innovative delivery, suggesting that the rapid and efficient dissemination of new technology should be given full consideration. In the service industry, element productivity was the most significant, indicating that it requires the conversion of productivity into products or services. For robustness, the survival rate was the most vital sub-factor in manufacturing, which suggests that the ability of a company to persist is the most important thing. For the service industry, experience and case continuity were the most important, showing that it is vital to withstand the changes in the external environment. For niche creation, manufacturer variety was considered as the most significant sub-factor by both industries, indicating that different types of companies are required to generate synergy.

For the active period, the most vital influential sub-factor in platform operation for the manufacturing industry was knowledge, since it is necessary to expand its scope. For the service industry, reputation was critical, suggesting the demand for building trust. For productivity, the most vital sub-factor in the manufacturing industry was element productivity, since it requires the conversion of productivity into products or services; and innovative delivery was the most vital sub-factor for the service industry, suggesting that the rapid and efficient dissemination of new technology should be given full consideration. For robustness, both industries considered survival rate as the most significant sub-factor, indicating that the ability of a company to persist is necessary for their survival. For niche creation, manufacturer diversity was the most vital sub-factor in the manufacturing industry, suggesting that different types of companies are required to generate synergy, whereas product and technology diversity was the most significant sub-factor in the service industry, indicating that newly created products or technologies are required. 
Table 15. Summary of keystone-type business strategy aspects and sub-factors of manufacturing industry.

\begin{tabular}{|c|c|c|c|c|c|c|c|c|c|c|c|c|c|c|}
\hline \multirow[b]{2}{*}{ Life Cycle } & \multicolumn{4}{|c|}{ Platform Operation } & \multicolumn{3}{|c|}{ Productivity } & \multicolumn{4}{|c|}{ Robustness } & \multicolumn{2}{|c|}{ Niche Creation } & \\
\hline & Technology & Partner & Reputation & Know-ledge & $\begin{array}{c}\text { Element } \\
\text { Productivity }\end{array}$ & $\begin{array}{l}\text { Productivity } \\
\text { Change }\end{array}$ & $\begin{array}{c}\text { Innovative } \\
\text { Delivery }\end{array}$ & $\begin{array}{c}\text { Survival } \\
\text { Rate }\end{array}$ & $\begin{array}{l}\text { Ecosystem } \\
\text { Structural } \\
\text { Durability }\end{array}$ & Predictability & $\begin{array}{l}\text { Experience and } \\
\text { Case Continuity }\end{array}$ & $\begin{array}{l}\text { Manufacturer } \\
\text { Diversity }\end{array}$ & $\begin{array}{c}\text { Product and } \\
\text { Technological } \\
\text { Diversity }\end{array}$ & \\
\hline \multirow{2}{*}{$\begin{array}{l}\text { Cohesion } \\
\text { Phase }\end{array}$} & \multicolumn{4}{|c|}{1} & \multicolumn{3}{|c|}{4} & \multicolumn{4}{|c|}{3} & \multicolumn{2}{|c|}{2} & $\mathrm{a}$ \\
\hline & 3 & 5 & 2 & 7 & 9 & 13 & 8 & 6 & 6 & 11 & 12 & 1 & 4 & $\mathrm{c}$ \\
\hline \multirow{3}{*}{ Active Phase } & \multicolumn{4}{|c|}{1} & \multicolumn{3}{|c|}{3} & \multicolumn{4}{|c|}{2} & \multicolumn{2}{|c|}{4} & $\mathrm{a}$ \\
\hline & 2 & 4 & 3 & 1 & 1 & 3 & 2 & 1 & 2 & 4 & 3 & 1 & 2 & $\mathrm{~b}$ \\
\hline & 4 & 9 & 6 & 5 & 3 & 5 & 10 & 1 & 11 & 13 & 12 & 2 & 8 & $\mathrm{c}$ \\
\hline \multirow{2}{*}{$\begin{array}{l}\text { Integration } \\
\text { Phase }\end{array}$} & 1 & 2 & 3 & 4 & 2 & 3 & 1 & 1 & 3 & 4 & 2 & 1 & 2 & $\mathrm{~b}$ \\
\hline & 1 & 3 & 7 & 8 & 6 & 10 & 4 & 9 & 12 & 13 & 11 & 2 & 5 & c \\
\hline \multirow{3}{*}{$\begin{array}{l}\text { Perpetual } \\
\text { Phase }\end{array}$} & \multicolumn{4}{|c|}{3} & \multicolumn{3}{|c|}{4} & \multicolumn{4}{|c|}{2} & \multicolumn{2}{|c|}{1} & $\mathrm{a}$ \\
\hline & 1 & 4 & 2 & 3 & 1 & 3 & 2 & 2 & 3 & 4 & 1 & 1 & 2 & $\mathrm{~b}$ \\
\hline & 5 & 11 & 6 & 10 & 9 & 13 & 12 & 4 & 7 & 8 & 3 & 1 & 2 & c \\
\hline
\end{tabular}

Note: (a) ranking of factors within the life cycle; (b) ranking of the sub-factor within each factor; (c) ranking of the sub-factor within the life cycle.

Table 16. Summary of keystone-type business strategy aspects and sub-factors of service industry.

\begin{tabular}{|c|c|c|c|c|c|c|c|c|c|c|c|c|c|c|}
\hline \multirow[b]{2}{*}{ Life Cycle } & \multicolumn{4}{|c|}{ Platform Operation } & \multicolumn{3}{|c|}{ Productivity } & \multicolumn{4}{|c|}{ Robustness } & \multicolumn{2}{|c|}{ Niche Creation } & \\
\hline & Technology & Partner & Reputation & Knowledge & $\begin{array}{c}\text { Element } \\
\text { Productivity }\end{array}$ & $\begin{array}{l}\text { Productivity } \\
\text { Change }\end{array}$ & $\begin{array}{l}\text { Innovative } \\
\text { Delivery }\end{array}$ & $\begin{array}{c}\text { Survival } \\
\text { Rate }\end{array}$ & $\begin{array}{l}\text { Ecosystem } \\
\text { Structural } \\
\text { Durability }\end{array}$ & Predictability & $\begin{array}{l}\text { Experience and } \\
\text { Case Continuity }\end{array}$ & $\begin{array}{l}\text { Manufacturer } \\
\text { Diversity }\end{array}$ & $\begin{array}{l}\text { Product and } \\
\text { Technological } \\
\text { Diversity }\end{array}$ & \\
\hline \multirow{2}{*}{$\begin{array}{l}\text { Cohesion } \\
\text { Phase }\end{array}$} & \multicolumn{4}{|c|}{1} & \multicolumn{3}{|c|}{4} & \multicolumn{4}{|c|}{3} & \multicolumn{2}{|r|}{2} & a \\
\hline & 5 & 2 & 4 & 3 & 9 & 13 & 10 & 7 & 8 & 12 & 11 & 1 & 6 & c \\
\hline \multirow{3}{*}{ Active Phase } & \multicolumn{4}{|c|}{1} & \multicolumn{3}{|c|}{2} & \multicolumn{4}{|c|}{3} & \multicolumn{2}{|c|}{4} & $\mathrm{a}$ \\
\hline & 3 & 2 & 1 & 4 & 3 & 2 & 1 & 3 & 2 & 4 & 1 & 2 & 1 & $\mathrm{~b}$ \\
\hline & 3 & 2 & 1 & 6 & 10 & 8 & 4 & 12 & 11 & 13 & 9 & 7 & 5 & $\mathrm{c}$ \\
\hline \multirow{2}{*}{$\begin{array}{l}\text { Integration } \\
\text { Phase }\end{array}$} & 2 & 3 & 4 & 1 & 3 & 2 & 1 & 3 & 1 & 2 & 4 & 2 & 1 & $\mathrm{~b}$ \\
\hline & 4 & 7 & 8 & 1 & 13 & 11 & 5 & 10 & 6 & 9 & 12 & 3 & 2 & $\mathrm{c}$ \\
\hline \multirow{3}{*}{$\begin{array}{l}\text { Perpetual } \\
\text { Phase }\end{array}$} & \multicolumn{4}{|c|}{3} & \multicolumn{3}{|c|}{4} & \multicolumn{4}{|c|}{2} & \multicolumn{2}{|c|}{1} & $\mathrm{a}$ \\
\hline & 1 & 3 & 2 & 4 & 3 & 2 & 1 & 1 & 2 & 3 & 4 & 2 & 1 & $\mathrm{~b}$ \\
\hline & 6 & 9 & 7 & 10 & 13 & 8 & 5 & 3 & 4 & 11 & 12 & 2 & 1 & $\mathrm{c}$ \\
\hline
\end{tabular}

Note: (a) ranking of factors within the life cycle; (b) ranking of the sub-factor within each aspect; (c) ranking of the sub-factor within the life cycle. 
For the integration period, both industries deemed technology as the most significant factor, indicating its importance as a core element. For productivity, both industries considered innovative delivery as the most important sub-factor, suggesting that the rapid and efficient dissemination of new technology should be given full consideration. For robustness, the survival rate was the most significant sub-factor, implying that the ability to persist is vital for a company. For niche creation, both industries viewed manufacturer diversity as the most significant, which indicates that different types of companies are required to generate synergy.

For the perpetual period, the most significant influential factor for the manufacturing industry was knowledge, signifying that the rapid and efficient dissemination of new technology should be taken into full account; while the service industry recognized element productivity as the most significant, indicating the urgent demand for reliable partners. For productivity, both industries perceived innovative delivery as the most important influential sub-factor, highlighting that the rapid and efficient dissemination of new technology should be given full consideration. For robustness, both industries considered survival rate as the most significant factor, suggesting that the ability to persist is important for a company. For niche creation, the most vital influential factor in the manufacturing industry was also the survival rate, whereas for the service industry, the manufacturer variety was considered a critical factor, which signifies that different types of companies are required to generate synergy.

In the agglomeration period, both industries perceived manufacturer variety as the most significant influential factor, which means that different types of companies are required to generate synergy. In the active period, the manufacturing industry believed that survival rate was the most vital factor, indicating the importance of the company's ability to persist, and the service industry considered reputation as the most important factor due to the demand of building trust at the beginning. In the integration period, technology was the most important influential factor for the manufacturing industry, highlighting its importance as a core element, whereas knowledge was the most vital factor for the service industry, indicating the necessity to expand its scope. In the perpetual period, the manufacturing industry considered manufacturer variety as the most significant factor, signifying that different types of companies are required to generate synergy, whereas product and technology variety was the most vital factor for the service industry, showing that newly created products or technologies are required to survive.

\subsection{The Limitation and Contribution}

The limitation of this study focuses on Taiwan SMEs' business ecosystem as an example, as well as the analysis and comparison of the keystone business strategy between the manufacturing and service industries. The manufacturing industry only has $18.67 \%$ in SMEs and $49.41 \%$ in SMEs' sales, but the service industry has $80.42 \%$ in SMEs and 50.42\% in SMEs' sales, which lead us to understand the fact that the manufacturing industry weighs higher than the service industry in Taiwan. The study contributes to clarify both the keystone's role in the manufacturing industry in Taiwan, and the important keystone business strategies that should be applied in the cluster of the life cycles of the manufacturing and service industries. The comparison of the difference between the manufacturing and service industries' keystone business strategies are presented in depth.

Author Contributions: Conceptualization, M.-K.C.; methodology, C.-M.W.; software, L.-S.C.; validation, M.-K.C.; formal analysis, L.-S.C.; investigation, M.-K.C.; resources, Y.-P.H.; data curation, L.-S.C.; writing-original draft preparation, L.-S.C.; writing-review and editing, M.-K.C.; visualization, L.-S.C. and C.-M.W.; project administration, L.-S.C.; funding acquisition, L.-S.C. All authors have read and agreed to the published version of the manuscript.

Funding: This research received no external funding.

Informed Consent Statement: Not applicable. 
Data Availability Statement: The study did not report any data.

Conflicts of Interest: The authors declare no conflict of interest.

\section{Appendix A}

Appendix A.1. Questionnaire Instructions

The questionnaire includes the following five parts:

1. Questionnaire instructions

2. Research factors and evaluation criteria

3. The FAHP questionnaire and the method for answering

4. The contents of the FAHP questionnaire

5. Basic background information

\section{Appendix A.2. Research Factors and Evaluation Criteria}

The evaluation framework of the keystone business strategy was divided using the four periods of the development life cycle: agglomeration period, active period, integration period, and perpetual period. The four aspects of the business ecosystem contain platform operations, niche creation, robustness, and productivity. The cluster development life cycle can be seen in Table A1.

Table A1. The cluster development life cycles.

\begin{tabular}{cc}
\hline Life Cycle & Explanations \\
\hline Agglomeration Phase & $\begin{array}{c}\text { The purpose is to establish the agglomeration force, emphasizing } \\
\text { integration degree, collective learning, and cluster collaboration } \\
\text { platform networks. }\end{array}$ \\
\hline Active Phase & $\begin{array}{c}\text { The purpose is to establish the active force, emphasizing the } \\
\text { marketing ability of cluster collaboration platform networks. }\end{array}$ \\
Integration Phase & $\begin{array}{c}\text { The purpose is to establish the integration force by hosting large-scale } \\
\text { exhibitions and sales and network activities based on local } \\
\text { government resources and establishing a stable marketing model and } \\
\text { cluster revenue mechanism. }\end{array}$ \\
\hline Perpetual Phase & $\begin{array}{c}\text { The purpose is to establish the perpetual force by establishing the } \\
\text { brand and mature operating mechanism using multiple channels. }\end{array}$ \\
\hline
\end{tabular}

The Role of a Business Ecosystem

(1) KeyStone: The health regulators of the business ecosystem are richly connected hubs with core technologies and can play a critical role in the vibrant and changing environment. With their professional knowledge, experience, technology, tools or status, they can effectively connect the human, material or social resources to create a mutually beneficial and symbiotic cooperation platform or provide altruistic assistance to other ecosystem members.

(2) Dominator: Species with core technologies or regulators in the whole business ecosystem can provide a platform for other system participants to create value like a keystone.

(3) Niche Player: The largest species in the ecosystem can use the platform and resources provided by key species (e.g., keystone) to develop SMEs business when facing a turbulent and changing environment. It can form development characteristics and expertise different from others to create unique value.

(4) Hub Landlord: Used to be a species with core technologies or regulating power in the ecosystem, which only focuses on seizing business value rather than creating their value. In other words, they mistook their influence and grabbed too much value without properly sharing the value with other participants.

Table A2 shows influential factors of keystone-type business strategy. 
Table A2. Influential factors of keystone-type business strategy.

\begin{tabular}{|c|c|c|}
\hline Factors & Sub-Factors & Explanations \\
\hline \multirow{4}{*}{ Platform Operation (A1) } & Technology (A1.1) & $\begin{array}{c}\text { Use of "technology" of the keystones to developing various } \\
\text { products }\end{array}$ \\
\hline & Partner (A1.2) & $\begin{array}{l}\text { Use of the "passengers" of the keystones to expand their } \\
\text { customer base }\end{array}$ \\
\hline & Reputation (A1.3) & $\begin{array}{l}\text { Use the "reputation" of the keystones to increase the trust of } \\
\text { channel providers and customers. }\end{array}$ \\
\hline & Knowledge (A1.4) & $\begin{array}{l}\text { Use of the "knowledge" of the keystones, including } \\
\text { "technical knowledge" and "management knowledge." }\end{array}$ \\
\hline \multirow{3}{*}{ Productivity (A2) } & Element Productivity (A2.1) & $\begin{array}{l}\text { Analyzes the ability of the members of a business ecosystem } \\
\text { to convert productivity into products }\end{array}$ \\
\hline & Productivity Changes (A2.2) & $\begin{array}{c}\text { The trends in the factors of productivity over a period of } \\
\text { time }\end{array}$ \\
\hline & Innovative Delivery (A2.3) & $\begin{array}{l}\text { Examines whether new technologies can be quickly and } \\
\text { effectively communicated among members of the business } \\
\text { ecosystem }\end{array}$ \\
\hline \multirow{4}{*}{ Robustness (A3) } & Survival Rate (A3.1) & $\begin{array}{l}\text { Demonstrates whether the members of the ecosystem have } \\
\text { a greater chance to survive compared with other ecosystems }\end{array}$ \\
\hline & $\begin{array}{l}\text { Ecosystem Structural } \\
\text { Durability (A3.2) }\end{array}$ & $\begin{array}{l}\text { Illustrates whether the structure of the ecosystem can } \\
\text { withstand changes from the external environment }\end{array}$ \\
\hline & Predictability (A3.3) & $\begin{array}{l}\text { The extent to which the changes in the ecosystem can be } \\
\text { predicted and controlled. }\end{array}$ \\
\hline & $\begin{array}{l}\text { Experience and Case } \\
\text { Continuity (A3.4) }\end{array}$ & $\begin{array}{l}\text { As consumers face new technology, their experience is } \\
\text { usually gradual, rather than drastic and substantial. }\end{array}$ \\
\hline \multirow{2}{*}{ Niche Creation (A4) } & Manufacturer Diversity (A4.1) & $\begin{array}{l}\text { Demonstrates the changes in the types of new companies } \\
\text { within a certain period of time }\end{array}$ \\
\hline & $\begin{array}{l}\text { Product and Technological } \\
\text { Diversity (A4.2) }\end{array}$ & $\begin{array}{l}\text { Demonstrates the changes in the number of newly created } \\
\text { products or technologies within a certain period of time }\end{array}$ \\
\hline
\end{tabular}

\section{Appendix A.3. The FAHP Questionnaire and the Method for Answering}

This research used the FAHP questionnaire, which compares the evaluation factors and assessment criteria with the nominal scale. It includes: absolutely important, extremely important, important, slightly important, and equally important. Measurement values are from 1 to 9; with numbers 9, 7, 5, 3, 1 assigned to the nominal scale and numbers of $8,6,4$, 2 assigned to the medium between the adjacent scales.

Table A3. Survey Questionnaire of Keystone-Type Business Strategy.

\section{Survey Questionnaire of Keystone-Type Business Strategy}

Note: This FAHP questionnaire aims to measure the importance of factor and subfactors in keystone-type business strategy, which compares the evaluation factors and assessment criteria with the nominal scale (pairwise comparison). It includes: absolutely important, extremely important, important, slightly important, and equally important. Measurement values are from 1 to 9 ; with numbers 9, 7, 5, 3, 1 assigned to the nominal scale and numbers of $8,6,4,2$ assigned to the medium between the adjacent scales as follows.

\begin{tabular}{ccc}
\hline Nominal Scale & Definition & Instructions \\
\hline 1 & Equally Important & Two criteria have the same importance \\
\hline 3 & Slightly Important & Experience and evaluation slightly value one criterion more than the other \\
\hline 5 & Important & Experience and evaluation strongly value one criterion more than the other \\
\hline 7 & Extremely Important & Experience and evaluation very strongly value one criterion more than the other \\
\hline $2,4,6,8$ & Absolutely Important & Experience and evaluation absolutely value one criterion more than the other \\
\hline
\end{tabular}




\section{Sample Instruction}

According to the experts, select keystone business strategies' factors and fill in the questionnaire based on how those factors count.

(1) As for "platform operation" and "productivity", experts believe that the former is slightly more important than the latter in the keystone business strategy. Give a 3-scale mark "slightly important" besides "platform operation".

(2) As for "platform operation" and "robustness", experts believe that the former is slightly more important than the latter in the keystone business strategy. Give a 5-scale mark "important" besides "platform operation".

(3) As for "platform operation" and "robustness", experts believe that the former is extremely more important than the latter in the keystone business strategy. Give a 7-scale mark "extremely important" besides "platform operation".

(4) As for "platform operation" and "robustness", experts believe that the latter is slightly more important than the former in the keystone business strategy. Give a 3-scale mark "slightly important" besides "robustness".

(5) As for "productivity" and "niche creation", experts believe that the latter is more important than the former in the keystone business strategy. Give a 5-scale mark "important" besides "niche creation".

(6) As for "robustness" and "niche creation", experts believe that the latter is extremely more important than the former in the keystone business strategy. Give a 7-scale mark "extremely important" besides "niche creation".

Table A4. Example table.

\begin{tabular}{|c|c|c|c|c|c|c|c|c|c|c|c|c|c|c|c|c|c|c|}
\hline \multirow{3}{*}{$\begin{array}{c}\text { Factors of Keystone } \\
\text { Business Strategy }\end{array}$} & \multicolumn{17}{|c|}{ Nominal Scale } & \multirow{3}{*}{$\begin{array}{c}\text { Factors of Keystone } \\
\text { Business Strategy }\end{array}$} \\
\hline & 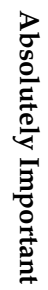 & & 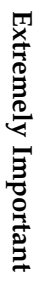 & & 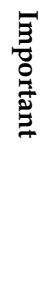 & & 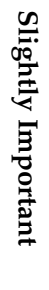 & & 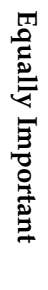 & & 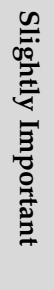 & & 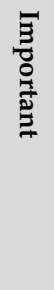 & & 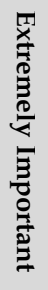 & & 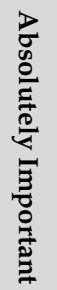 & \\
\hline & 9 & 8 & 7 & 6 & 5 & 4 & 3 & 2 & 1 & 2 & 3 & 4 & 5 & 6 & 7 & 8 & 9 & \\
\hline \multirow{3}{*}{ Platform Operation (A1) } & & & & & & & & & & & & & & & & & & Productivity (A2) \\
\hline & & & & & & & & & & & & & & & & & & Robustness (A3) \\
\hline & & & & & & & & & & & & & & & & & & Niche Creation (A4) \\
\hline \multirow{2}{*}{ Productivity (A2) } & & & & & & & & & & & & & & & & & & Robustness (A3) \\
\hline & & & & & & & & & & & & & & & & & & Niche Creation (A4) \\
\hline Robustness (A3) & & & & & & & & & & & & & & & & & & Niche Creation (A4) \\
\hline
\end{tabular}




\section{Appendix A.4. The Contents of the FAHP Questionnaire}

Appendix A.4.1. The Importance of Factors Influencing Keystone Business Strategy

Table A5. Agglomeration Period.

\begin{tabular}{|c|c|c|c|c|c|c|c|c|c|c|c|c|c|c|c|c|c|c|}
\hline \multirow{3}{*}{$\begin{array}{c}\text { Factors of Keystone } \\
\text { Business Strategy }\end{array}$} & \multicolumn{17}{|c|}{ Nominal Scale } & \multirow{3}{*}{$\begin{array}{c}\text { Factors of Keystone } \\
\text { Business Strategy }\end{array}$} \\
\hline & 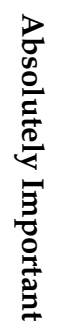 & & 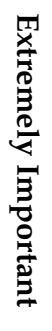 & & 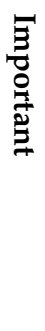 & & 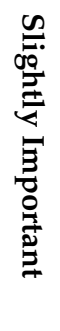 & & 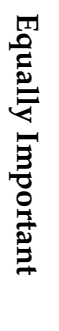 & & 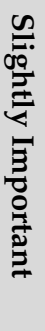 & & 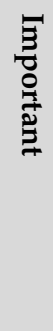 & & 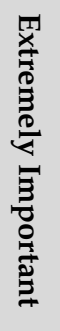 & & 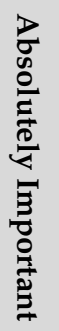 & \\
\hline & 9 & 8 & 7 & 6 & 5 & 4 & 3 & 2 & 1 & 2 & 3 & 4 & 5 & 6 & 7 & 8 & 9 & \\
\hline \multirow{3}{*}{$\begin{array}{l}\text { Platform Operation } \\
\text { (A1) }\end{array}$} & & & & & & & & & & & & & & & & & & Productivity (A2) \\
\hline & & & & & & & & & & & & & & & & & & Robustness (A3) \\
\hline & & & & & & & & & & & & & & & & & & Niche Creation (A4) \\
\hline \multirow{2}{*}{ Productivity (A2) } & & & & & & & & & & & & & & & & & & Robustness (A3) \\
\hline & & & & & & & & & & & & & & & & & & Niche Creation (A4) \\
\hline Robustness (A3) & & & & & & & & & & & & & & & & & & Niche Creation (A4) \\
\hline
\end{tabular}

Table A6. Active period.

\begin{tabular}{|c|c|c|c|c|c|c|c|c|c|c|c|c|c|c|c|c|c|c|}
\hline \multirow{3}{*}{$\begin{array}{c}\text { Factors of Keystone } \\
\text { Business Strategy }\end{array}$} & \multicolumn{17}{|c|}{ Nominal Scale } & \multirow{3}{*}{$\begin{array}{c}\text { Factors of Keystone } \\
\text { Business Strategy }\end{array}$} \\
\hline & 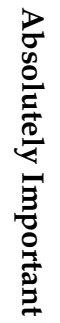 & & 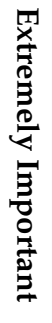 & & 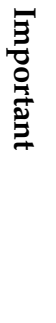 & & 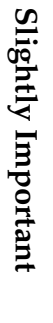 & & 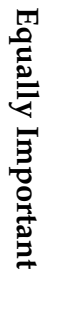 & & 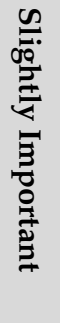 & & 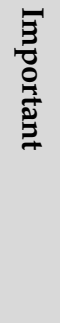 & & 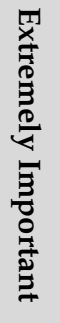 & & 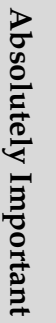 & \\
\hline & 9 & 8 & 7 & 6 & 5 & 4 & 3 & 2 & 1 & 2 & 3 & 4 & 5 & 6 & 7 & 8 & 9 & \\
\hline \multirow{3}{*}{$\begin{array}{l}\text { Platform Operation } \\
\text { (A1) }\end{array}$} & & & & & & & & & & & & & & & & & & Productivity (A2) \\
\hline & & & & & & & & & & & & & & & & & & Robustness (A3) \\
\hline & & & & & & & & & & & & & & & & & & Niche Creation (A4) \\
\hline \multirow{2}{*}{ Productivity (A2) } & & & & & & & & & & & & & & & & & & Robustness (A3) \\
\hline & & & & & & & & & & & & & & & & & & Niche Creation (A4) \\
\hline Robustness (A3) & & & & & & & & & & & & & & & & & & Niche Creation (A4) \\
\hline
\end{tabular}


Table A7. Integration period.

\begin{tabular}{|c|c|c|c|c|c|c|c|c|c|c|c|c|c|c|c|c|c|c|}
\hline \multirow{3}{*}{$\begin{array}{c}\text { Factors of Keystone } \\
\text { Business Strategy }\end{array}$} & \multicolumn{17}{|c|}{ Nominal Scale } & \multirow{3}{*}{$\begin{array}{c}\text { Factors of Keystone } \\
\text { Business Strategy }\end{array}$} \\
\hline & 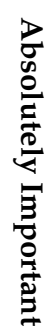 & & 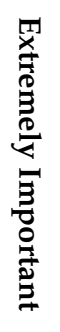 & & 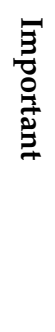 & & 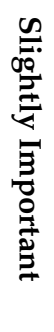 & & 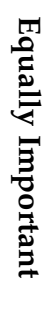 & & 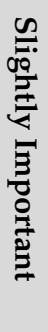 & & 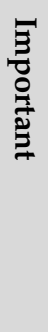 & & 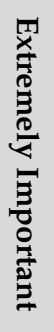 & & 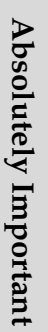 & \\
\hline & 9 & 8 & 7 & 6 & 5 & 4 & 3 & 2 & 1 & 2 & 3 & 4 & 5 & 6 & 7 & 8 & 9 & \\
\hline \multirow{3}{*}{$\begin{array}{l}\text { Platform Operation } \\
\text { (A1) }\end{array}$} & & & & & & & & & & & & & & & & & & Productivity (A2) \\
\hline & & & & & & & & & & & & & & & & & & Robustness (A3) \\
\hline & & & & & & & & & & & & & & & & & & Niche Creation (A4) \\
\hline \multirow{2}{*}{ Productivity (A2) } & & & & & & & & & & & & & & & & & & Robustness (A3) \\
\hline & & & & & & & & & & & & & & & & & & Niche Creation (A4) \\
\hline Robustness (A3) & & & & & & & & & & & & & & & & & & Niche Creation (A4) \\
\hline
\end{tabular}

Table A8. Perpetual period.

\begin{tabular}{|c|c|c|c|c|c|c|c|c|c|c|c|c|c|c|c|c|c|c|}
\hline \multirow{3}{*}{$\begin{array}{c}\text { Factors of Keystone } \\
\text { Business Strategy }\end{array}$} & \multicolumn{17}{|c|}{ Nominal Scale } & \multirow{3}{*}{$\begin{array}{c}\text { Factors of Keystone } \\
\text { Business Strategy }\end{array}$} \\
\hline & 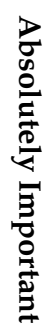 & & 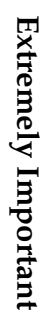 & & 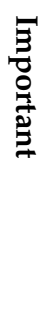 & & 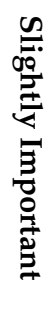 & & 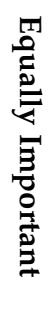 & & 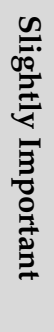 & & 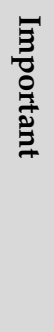 & & 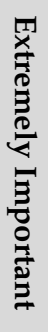 & & 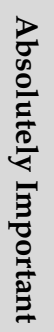 & \\
\hline & 9 & 8 & 7 & 6 & 5 & 4 & 3 & 2 & 1 & 2 & 3 & 4 & 5 & 6 & 7 & 8 & 9 & \\
\hline \multirow{3}{*}{$\begin{array}{l}\text { Platform Operation } \\
\text { (A1) }\end{array}$} & & & & & & & & & & & & & & & & & & Productivity (A2) \\
\hline & & & & & & & & & & & & & & & & & & Robustness (A3) \\
\hline & & & & & & & & & & & & & & & & & & Niche Creation (A4) \\
\hline \multirow{2}{*}{ Productivity (A2) } & & & & & & & & & & & & & & & & & & Robustness (A3) \\
\hline & & & & & & & & & & & & & & & & & & Niche Creation (A4) \\
\hline Robustness (A3) & & & & & & & & & & & & & & & & & & Niche Creation (A4) \\
\hline
\end{tabular}


Appendix A.4.2. The Relative Importance of Subfactors of Platform Operation

Table A9. Agglomeration period.

\begin{tabular}{|c|c|c|c|c|c|c|c|c|c|c|c|c|c|c|c|c|c|c|}
\hline \multirow{3}{*}{$\begin{array}{c}\text { Sub-Factors of } \\
\text { Platform Operation }\end{array}$} & \multicolumn{17}{|c|}{ Nominal Scale } & \multirow{3}{*}{$\begin{array}{c}\text { Sub-Factors of } \\
\text { Platform Operation }\end{array}$} \\
\hline & 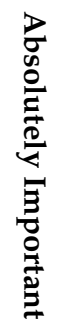 & & 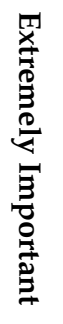 & & 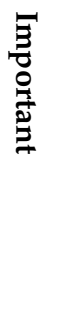 & & 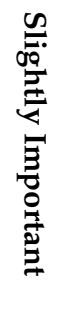 & & 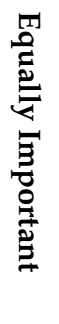 & & 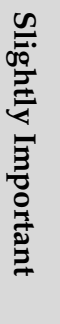 & & 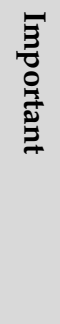 & & 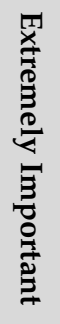 & & 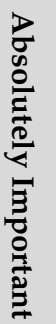 & \\
\hline & 9 & 8 & 7 & 6 & 5 & 4 & 3 & 2 & 1 & 2 & 3 & 4 & 5 & 6 & 7 & 8 & 9 & \\
\hline \multirow{3}{*}{ Technology (A1.1) } & & & & & & & & & & & & & & & & & & Partner (A1.2) \\
\hline & & & & & & & & & & & & & & & & & & Reputation (A1.3) \\
\hline & & & & & & & & & & & & & & & & & & Knowledge (A1.4) \\
\hline \multirow{2}{*}{ Partner (A1.2) } & & & & & & & & & & & & & & & & & & Reputation (A1.3) \\
\hline & & & & & & & & & & & & & & & & & & Knowledge (A1.4) \\
\hline Reputation (A1.3) & & & & & & & & & & & & & & & & & & Knowledge (A1.4) \\
\hline
\end{tabular}

Table A10. Active period.

\begin{tabular}{|c|c|c|c|c|c|c|c|c|c|c|c|c|c|c|c|c|c|c|}
\hline \multirow{3}{*}{$\begin{array}{l}\text { Sub-Factors of } \\
\text { Platform Operation }\end{array}$} & \multicolumn{17}{|c|}{ Nominal Scale } & \multirow{3}{*}{$\begin{array}{c}\text { Sub-Factors of } \\
\text { Platform Operation }\end{array}$} \\
\hline & 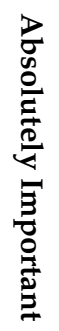 & & 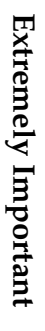 & & 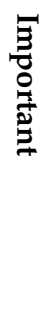 & & 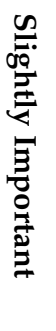 & & 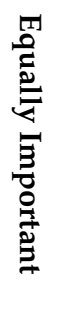 & & 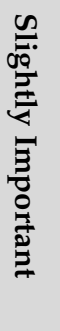 & & 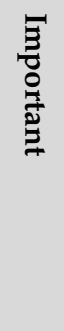 & & 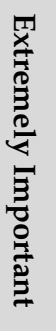 & & 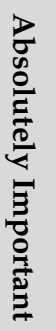 & \\
\hline & 9 & 8 & 7 & 6 & 5 & 4 & 3 & 2 & 1 & 2 & 3 & 4 & 5 & 6 & 7 & 8 & 9 & \\
\hline \multirow{3}{*}{ Technology (A1.1) } & & & & & & & & & & & & & & & & & & Partner (A1.2) \\
\hline & & & & & & & & & & & & & & & & & & Reputation (A1.3) \\
\hline & & & & & & & & & & & & & & & & & & Knowledge (A1.4) \\
\hline \multirow{2}{*}{ Partner (A1.2) } & & & & & & & & & & & & & & & & & & Reputation (A1.3) \\
\hline & & & & & & & & & & & & & & & & & & Knowledge (A1.4) \\
\hline Reputation (A1.3) & & & & & & & & & & & & & & & & & & Knowledge (A1.4) \\
\hline
\end{tabular}


Table A11. Integration period.

\begin{tabular}{|c|c|c|c|c|c|c|c|c|c|c|c|c|c|c|c|c|c|c|}
\hline \multirow{3}{*}{$\begin{array}{c}\text { Sub-Factors of } \\
\text { Platform Operation }\end{array}$} & \multicolumn{17}{|c|}{ Nominal Scale } & \multirow{3}{*}{$\begin{array}{c}\text { Sub-Factors of } \\
\text { Platform Operation }\end{array}$} \\
\hline & 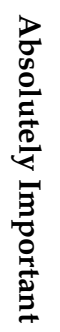 & & 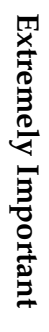 & & 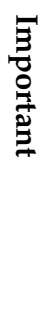 & & 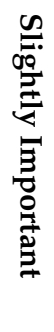 & & 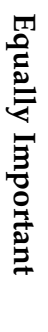 & & 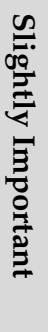 & & 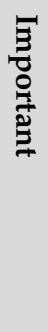 & & 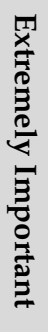 & & 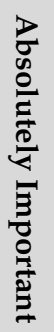 & \\
\hline & 9 & 8 & 7 & 6 & 5 & 4 & 3 & 2 & 1 & 2 & 3 & 4 & 5 & 6 & 7 & 8 & 9 & \\
\hline \multirow{3}{*}{ Technology (A1.1) } & & & & & & & & & & & & & & & & & & Partner (A1.2) \\
\hline & & & & & & & & & & & & & & & & & & Reputation (A1.3) \\
\hline & & & & & & & & & & & & & & & & & & Knowledge (A1.4) \\
\hline \multirow{2}{*}{ Partner (A1.2) } & & & & & & & & & & & & & & & & & & Reputation (A1.3) \\
\hline & & & & & & & & & & & & & & & & & & Knowledge (A1.4) \\
\hline Reputation (A1.3) & & & & & & & & & & & & & & & & & & Knowledge (A1.4) \\
\hline
\end{tabular}

Table A12. Perpetual period.

\begin{tabular}{|c|c|c|c|c|c|c|c|c|c|c|c|c|c|c|c|c|c|c|}
\hline \multirow{3}{*}{$\begin{array}{c}\text { Sub-Factors of } \\
\text { Platform Operation }\end{array}$} & \multicolumn{17}{|c|}{ Nominal Scale } & \multirow{3}{*}{$\begin{array}{c}\text { Sub-Factors of } \\
\text { Platform Operation }\end{array}$} \\
\hline & 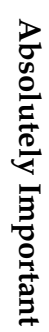 & & 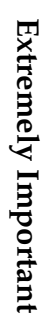 & & 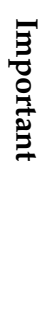 & & 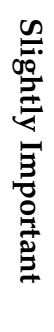 & & 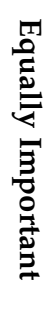 & & 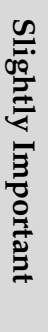 & & 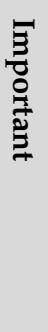 & & 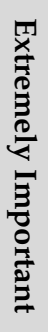 & & 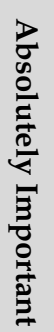 & \\
\hline & 9 & 8 & 7 & 6 & 5 & 4 & 3 & 2 & 1 & 2 & 3 & 4 & 5 & 6 & 7 & 8 & 9 & \\
\hline \multirow{3}{*}{ Technology (A1.1) } & & & & & & & & & & & & & & & & & & Partner (A1.2) \\
\hline & & & & & & & & & & & & & & & & & & Reputation (A1.3) \\
\hline & & & & & & & & & & & & & & & & & & Knowledge (A1.4) \\
\hline \multirow{2}{*}{ Partner (A1.2) } & & & & & & & & & & & & & & & & & & Reputation (A1.3) \\
\hline & & & & & & & & & & & & & & & & & & Knowledge (A1.4) \\
\hline Reputation (A1.3) & & & & & & & & & & & & & & & & & & Knowledge (A1.4) \\
\hline
\end{tabular}


Appendix A.4.3. The Relative Importance of Subfactors of Productivity

Table A13. Agglomeration period.

\begin{tabular}{|c|c|c|c|c|c|c|c|c|c|c|c|c|c|c|c|c|c|}
\hline \multirow{3}{*}{$\begin{array}{l}\text { Sub-Factors of } \\
\text { Productivity }\end{array}$} & \multicolumn{16}{|c|}{ Nominal Scale } & \multirow{3}{*}{$\begin{array}{c}\text { Sub-Factors of } \\
\text { Productivity }\end{array}$} \\
\hline & 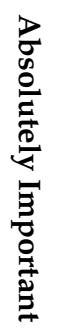 & & 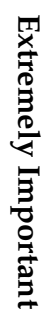 & & 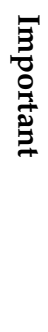 & & 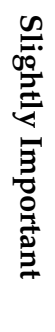 & & 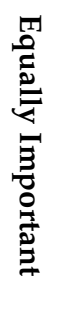 & & 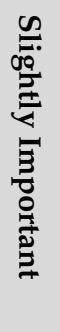 & & 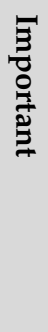 & & 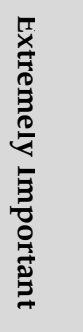 & 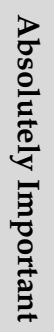 & \\
\hline & 9 & 8 & 7 & 6 & 5 & 4 & 3 & 2 & 1 & 2 & 3 & 4 & 5 & 6 & 78 & 9 & \\
\hline \multirow{2}{*}{$\begin{array}{l}\text { Element Productivity } \\
\text { (A2.1) }\end{array}$} & & & & & & & & & & & & & & & & & $\begin{array}{c}\text { Productivity } \\
\text { Changes (A2.2) }\end{array}$ \\
\hline & & & & & & & & & & & & & & & & & $\begin{array}{c}\text { Innovative } \\
\text { Delivery (A2.3) }\end{array}$ \\
\hline $\begin{array}{l}\text { Productivity Changes } \\
\text { (A2.2) }\end{array}$ & & & & & & & & & & & & & & & & & $\begin{array}{c}\text { Innovative } \\
\text { Delivery (A2.3) }\end{array}$ \\
\hline
\end{tabular}

Table A14. Active period.

\begin{tabular}{|c|c|c|c|c|c|c|c|c|c|c|c|c|c|c|c|c|c|}
\hline \multirow{3}{*}{$\begin{array}{l}\text { Sub-Factors of } \\
\text { Productivity }\end{array}$} & \multicolumn{16}{|c|}{ Nominal Scale } & \multirow{3}{*}{$\begin{array}{c}\text { Sub-Factors of } \\
\text { Productivity }\end{array}$} \\
\hline & 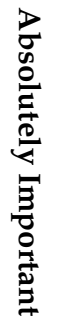 & & 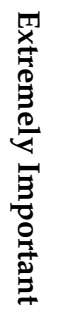 & & 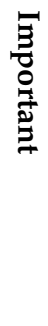 & & 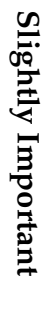 & & 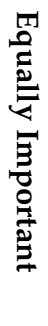 & & 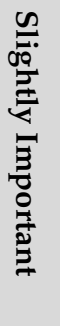 & & 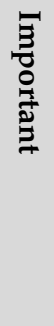 & & 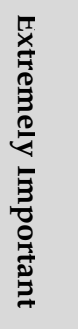 & 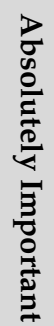 & \\
\hline & 9 & 8 & 7 & 6 & 5 & 4 & 3 & 2 & 1 & 2 & 3 & 4 & 5 & 6 & 78 & 9 & \\
\hline \multirow{2}{*}{$\begin{array}{l}\text { Element Productivity } \\
\text { (A2.1) }\end{array}$} & & & & & & & & & & & & & & & & & $\begin{array}{c}\text { Productivity } \\
\text { Changes (A2.2) }\end{array}$ \\
\hline & & & & & & & & & & & & & & & & & $\begin{array}{c}\text { Innovative } \\
\text { Delivery (A2.3) }\end{array}$ \\
\hline $\begin{array}{l}\text { Productivity Changes } \\
\text { (A2.2) }\end{array}$ & & & & & & & & & & & & & & & & & $\begin{array}{c}\text { Innovative } \\
\text { Delivery (A2.3) }\end{array}$ \\
\hline
\end{tabular}


Table A15. Integration period.

\begin{tabular}{|c|c|c|c|c|c|c|c|c|c|c|c|c|c|c|c|c|c|}
\hline \multirow{3}{*}{$\begin{array}{l}\text { Sub-Factors of } \\
\text { Productivity }\end{array}$} & \multicolumn{16}{|c|}{ Nominal Scale } & \multirow{3}{*}{$\begin{array}{c}\text { Sub-Factors of } \\
\text { Productivity }\end{array}$} \\
\hline & 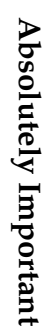 & & 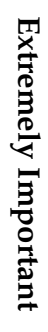 & & 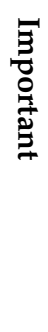 & & 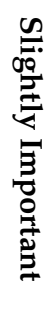 & & 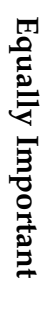 & & 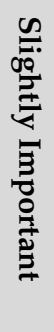 & & 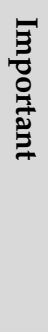 & & 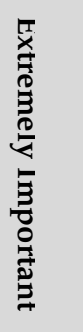 & 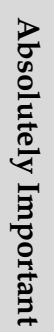 & \\
\hline & 9 & 8 & 7 & 6 & 5 & 4 & 3 & 2 & 1 & 2 & 3 & 4 & 5 & 6 & 78 & 9 & \\
\hline \multirow{2}{*}{$\begin{array}{l}\text { Element Productivity } \\
\text { (A2.1) }\end{array}$} & & & & & & & & & & & & & & & & & $\begin{array}{c}\text { Productivity } \\
\text { Changes (A2.2) }\end{array}$ \\
\hline & & & & & & & & & & & & & & & & & $\begin{array}{c}\text { Innovative } \\
\text { Delivery (A2.3) }\end{array}$ \\
\hline $\begin{array}{c}\text { Productivity Changes } \\
\text { (A2.2) }\end{array}$ & & & & & & & & & & & & & & & & & $\begin{array}{c}\text { Innovative } \\
\text { Delivery (A2.3) }\end{array}$ \\
\hline
\end{tabular}

Table A16. Perpetual period.

\begin{tabular}{|c|c|c|c|c|c|c|c|c|c|c|c|c|c|c|c|c|c|}
\hline \multirow{3}{*}{$\begin{array}{l}\text { Sub-Factors of } \\
\text { Productivity }\end{array}$} & \multicolumn{16}{|c|}{ Nominal Scale } & \multirow{3}{*}{$\begin{array}{c}\text { Sub-Factors of } \\
\text { Productivity }\end{array}$} \\
\hline & 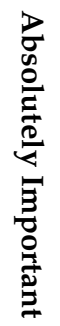 & & 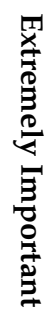 & & 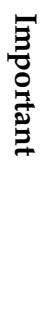 & & 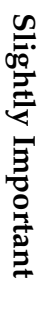 & & 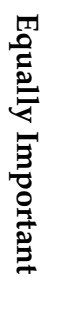 & & 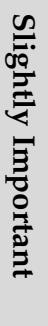 & & 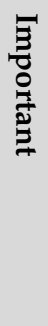 & & 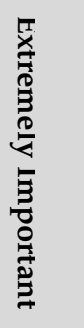 & 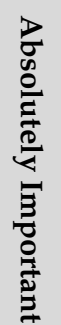 & \\
\hline & 9 & 8 & 7 & 6 & 5 & 4 & 3 & 2 & 1 & 2 & 3 & 4 & 5 & 6 & 78 & 9 & \\
\hline \multirow{2}{*}{$\begin{array}{l}\text { Element Productivity } \\
\text { (A2.1) }\end{array}$} & & & & & & & & & & & & & & & & & $\begin{array}{c}\text { Productivity } \\
\text { Changes (A2.2) }\end{array}$ \\
\hline & & & & & & & & & & & & & & & & & $\begin{array}{c}\text { Innovative } \\
\text { Delivery (A2.3) }\end{array}$ \\
\hline $\begin{array}{c}\text { Productivity Changes } \\
\text { (A2.2) }\end{array}$ & & & & & & & & & & & & & & & & & $\begin{array}{c}\text { Innovative } \\
\text { Delivery (A2.3) }\end{array}$ \\
\hline
\end{tabular}


Appendix A.4.4. The Relative Importance of Subfactors of Robustness

Table A17. Agglomeration period.

\begin{tabular}{|c|c|c|c|c|c|c|c|c|c|c|c|c|c|c|c|c|c|c|}
\hline \multirow{3}{*}{$\begin{array}{l}\text { Sub-Factors of } \\
\text { Robustness }\end{array}$} & \multicolumn{17}{|c|}{ Nominal Scale } & \multirow{3}{*}{$\begin{array}{l}\text { Sub-Factors of } \\
\text { Robustness }\end{array}$} \\
\hline & 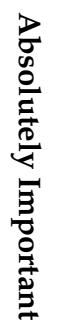 & & 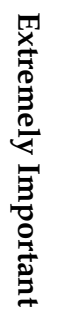 & & 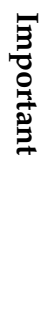 & & 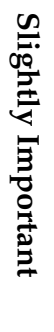 & & 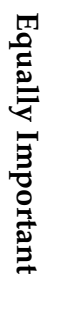 & & 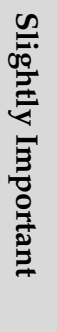 & & 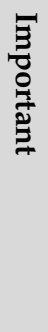 & & 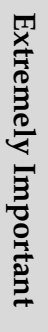 & & 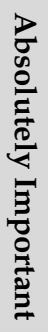 & \\
\hline & 9 & 8 & 7 & 6 & 5 & 4 & 3 & 2 & 1 & 2 & 3 & 4 & 5 & 6 & 7 & 8 & 9 & \\
\hline \multirow{3}{*}{ Survival Rate (A3.1) } & & & & & & & & & & & & & & & & & & $\begin{array}{l}\text { Ecosystem Structure } \\
\text { Durability (A3.2) }\end{array}$ \\
\hline & & & & & & & & & & & & & & & & & & Predictability (A3.3) \\
\hline & & & & & & & & & & & & & & & & & & $\begin{array}{c}\text { Experience and Case } \\
\text { Continuity (A3.4) }\end{array}$ \\
\hline \multirow{2}{*}{$\begin{array}{c}\text { Ecosystem Structure } \\
\text { Durability (A3.2) }\end{array}$} & & & & & & & & & & & & & & & & & & Predictability (A3.3) \\
\hline & & & & & & & & & & & & & & & & & & $\begin{array}{l}\text { Experience and Case } \\
\text { Continuity (A3.4) }\end{array}$ \\
\hline Predictability (A3.3) & & & & & & & & & & & & & & & & & & $\begin{array}{c}\text { Experience and Case } \\
\text { Continuity (A3.4) }\end{array}$ \\
\hline
\end{tabular}

Table A18. Active period.

\begin{tabular}{|c|c|c|c|c|c|c|c|c|c|c|c|c|c|c|c|c|c|c|}
\hline \multirow{3}{*}{$\begin{array}{l}\text { Sub-Factors of } \\
\text { Robustness }\end{array}$} & \multicolumn{17}{|c|}{ Nominal Scale } & \multirow{3}{*}{$\begin{array}{l}\text { Sub-Factors of } \\
\text { Robustness }\end{array}$} \\
\hline & 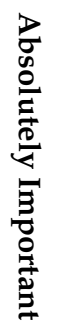 & & 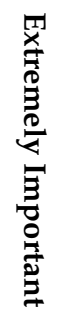 & & 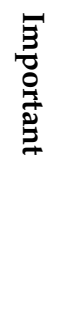 & & 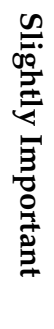 & & 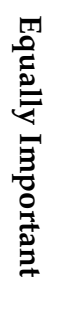 & & 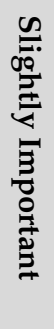 & & 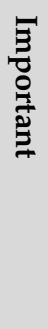 & & 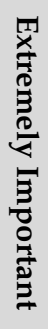 & & 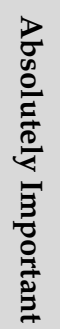 & \\
\hline & 9 & 8 & 7 & 6 & 5 & 4 & 3 & 2 & 1 & 2 & 3 & 4 & 5 & 6 & 7 & 8 & 9 & \\
\hline \multirow{3}{*}{ Survival Rate (A3.1) } & & & & & & & & & & & & & & & & & & $\begin{array}{c}\text { Ecosystem Structure } \\
\text { Durability (A3.2) }\end{array}$ \\
\hline & & & & & & & & & & & & & & & & & & Predictability (A3.3) \\
\hline & & & & & & & & & & & & & & & & & & $\begin{array}{c}\text { Experience and Case } \\
\text { Continuity (A3.4) }\end{array}$ \\
\hline \multirow{2}{*}{$\begin{array}{l}\text { Ecosystem Structure } \\
\text { Durability (A3.2) }\end{array}$} & & & & & & & & & & & & & & & & & & Predictability (A3.3) \\
\hline & & & & & & & & & & & & & & & & & & $\begin{array}{c}\text { Experience and Case } \\
\text { Continuity (A3.4) }\end{array}$ \\
\hline Predictability (A3.3) & & & & & & & & & & & & & & & & & & $\begin{array}{c}\text { Experience and Case } \\
\text { Continuity (A3.4) }\end{array}$ \\
\hline
\end{tabular}


Table A19. Integration period.

\begin{tabular}{|c|c|c|c|c|c|c|c|c|c|c|c|c|c|c|c|c|c|c|}
\hline \multirow{3}{*}{$\begin{array}{l}\text { Sub-Factors of } \\
\text { Robustness }\end{array}$} & \multicolumn{17}{|c|}{ Nominal Scale } & \multirow{3}{*}{$\begin{array}{l}\text { Sub-Factors of } \\
\text { Robustness }\end{array}$} \\
\hline & 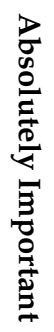 & & 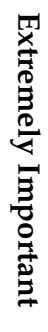 & & 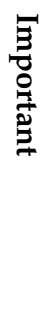 & & 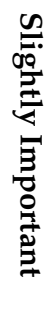 & & 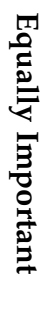 & & 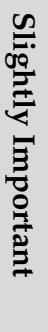 & & 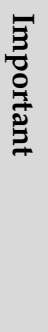 & & 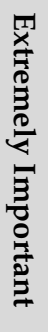 & & 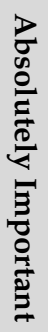 & \\
\hline & 9 & 8 & 7 & 6 & 5 & 4 & 3 & 2 & 1 & 2 & 3 & 4 & 5 & 6 & 7 & 8 & 9 & \\
\hline \multirow{3}{*}{ Survival Rate (A3.1) } & & & & & & & & & & & & & & & & & & $\begin{array}{c}\text { Ecosystem Structure } \\
\text { Durability (A3.2) }\end{array}$ \\
\hline & & & & & & & & & & & & & & & & & & Predictability (A3.3) \\
\hline & & & & & & & & & & & & & & & & & & $\begin{array}{c}\text { Experience and Case } \\
\text { Continuity (A3.4) }\end{array}$ \\
\hline \multirow[b]{2}{*}{$\begin{array}{l}\text { Ecosystem Structure } \\
\text { Durability (A3.2) }\end{array}$} & & & & & & & & & & & & & & & & & & Predictability (A3.3) \\
\hline & & & & & & & & & & & & & & & & & & $\begin{array}{c}\text { Experience and Case } \\
\text { Continuity (A3.4) }\end{array}$ \\
\hline Predictability (A3.3) & & & & & & & & & & & & & & & & & & $\begin{array}{c}\text { Experience and Case } \\
\text { Continuity (A3.4) }\end{array}$ \\
\hline
\end{tabular}

Table A20. Perpetual period.

\begin{tabular}{|c|c|c|c|c|c|c|c|c|c|c|c|c|c|c|c|c|c|c|}
\hline \multirow{3}{*}{$\begin{array}{l}\text { Sub-Factors of } \\
\text { Robustness }\end{array}$} & \multicolumn{17}{|c|}{ Nominal Scale } & \multirow{3}{*}{$\begin{array}{l}\text { Sub-Factors of } \\
\text { Robustness }\end{array}$} \\
\hline & 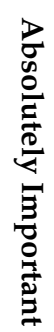 & & 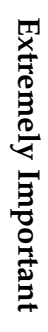 & & 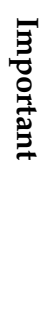 & & 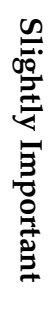 & & 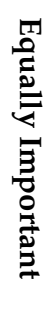 & & 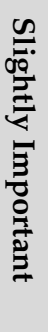 & & 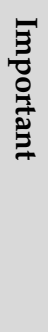 & & 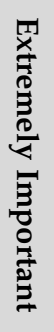 & & 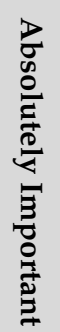 & \\
\hline & 9 & 8 & 7 & 6 & 5 & 4 & 3 & 2 & 1 & 2 & 3 & 4 & 5 & 6 & 7 & 8 & 9 & \\
\hline \multirow{3}{*}{ Survival Rate (A3.1) } & & & & & & & & & & & & & & & & & & $\begin{array}{c}\text { Ecosystem Structure } \\
\text { Durability (A3.2) }\end{array}$ \\
\hline & & & & & & & & & & & & & & & & & & Predictability (A3.3) \\
\hline & & & & & & & & & & & & & & & & & & $\begin{array}{c}\text { Experience and Case } \\
\text { Continuity (A3.4) }\end{array}$ \\
\hline \multirow{2}{*}{$\begin{array}{c}\text { Ecosystem Structure } \\
\text { Durability (A3.2) }\end{array}$} & & & & & & & & & & & & & & & & & & Predictability (A3.3) \\
\hline & & & & & & & & & & & & & & & & & & $\begin{array}{c}\text { Experience and Case } \\
\text { Continuity (A3.4) }\end{array}$ \\
\hline Predictability (A3.3) & & & & & & & & & & & & & & & & & & $\begin{array}{c}\text { Experience and Case } \\
\text { Continuity (A3.4) }\end{array}$ \\
\hline
\end{tabular}


Appendix A.4.5. The Relative Importance of Subfactors of Niche Creation

Table A21. Agglomeration period.

\begin{tabular}{|c|c|c|c|c|c|c|c|c|c|c|c|c|c|c|c|c|c|}
\hline \multirow{3}{*}{$\begin{array}{l}\text { Sub-Factors of Niche } \\
\text { Creation }\end{array}$} & \multicolumn{16}{|c|}{ Nominal Scale } & \multirow{3}{*}{$\begin{array}{l}\text { Sub-Factors of } \\
\text { Niche Creation }\end{array}$} \\
\hline & 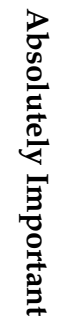 & & 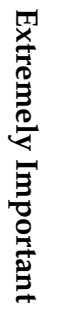 & & 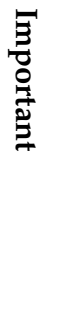 & & 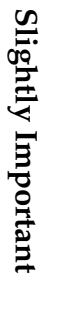 & & 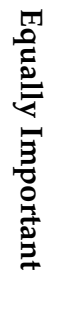 & & 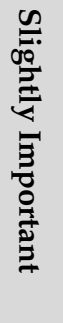 & & 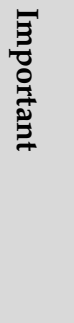 & 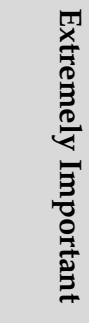 & & 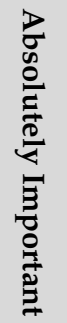 & \\
\hline & 9 & 8 & 7 & 6 & 5 & 4 & 3 & 2 & 1 & 2 & 3 & 4 & 5 & 67 & 8 & 9 & \\
\hline $\begin{array}{l}\text { Manufacturer } \\
\text { Diversity (A4.1) }\end{array}$ & & & & & & & & & & & & & & & & & $\begin{array}{c}\text { Product and } \\
\text { Technology Diversity } \\
\text { (A4.2) }\end{array}$ \\
\hline
\end{tabular}

Table A22. Active period.

\begin{tabular}{|c|c|c|c|c|c|c|c|c|c|c|c|c|c|c|c|c|}
\hline \multirow{3}{*}{$\begin{array}{l}\text { Sub-Factors of Niche } \\
\text { Creation }\end{array}$} & \multicolumn{15}{|c|}{ Nominal Scale } & \multirow{3}{*}{$\begin{array}{l}\text { Sub-Factors of } \\
\text { Niche Creation }\end{array}$} \\
\hline & 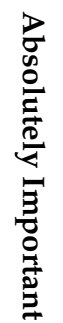 & & 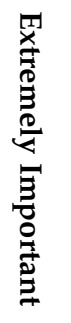 & & 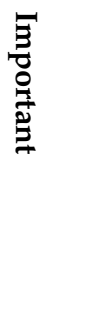 & 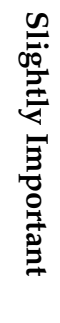 & & 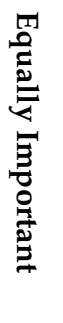 & & 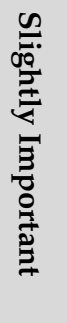 & & 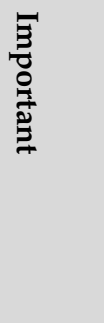 & 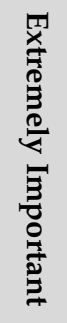 & & 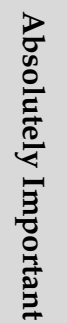 & \\
\hline & 9 & 8 & 7 & 6 & $\begin{array}{ll}5 & 4 \\
\end{array}$ & 3 & 2 & 1 & 2 & 3 & 4 & $\begin{array}{ll}5 & 6\end{array}$ & 7 & 8 & 9 & \\
\hline $\begin{array}{l}\text { Manufacturer } \\
\text { Diversity (A4.1) }\end{array}$ & & & & & & & & & & & & & & & & $\begin{array}{c}\text { Product and } \\
\text { Technology Diversity } \\
\text { (A4.2) }\end{array}$ \\
\hline
\end{tabular}

Table A23. Integration period.

\begin{tabular}{|c|c|c|c|c|c|c|c|c|c|c|c|c|c|c|c|c|c|c|}
\hline \multirow{3}{*}{$\begin{array}{c}\text { Sub-Factors of Niche } \\
\text { Creation }\end{array}$} & \multicolumn{17}{|c|}{ Nominal Scale } & \multirow{3}{*}{$\begin{array}{l}\text { Sub-Factors of } \\
\text { Niche Creation }\end{array}$} \\
\hline & 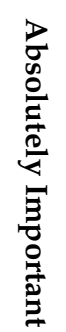 & & 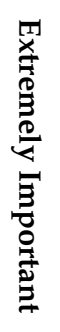 & & 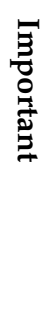 & & 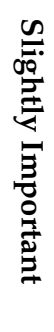 & & 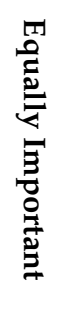 & & 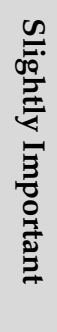 & & 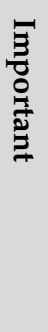 & & 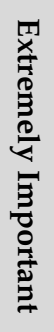 & & 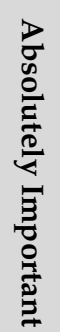 & \\
\hline & 9 & 8 & 7 & 6 & 5 & 4 & 3 & 2 & 1 & 2 & 3 & 4 & 5 & 6 & 7 & 8 & 9 & \\
\hline $\begin{array}{l}\text { Manufacturer } \\
\text { Diversity (A4.1) }\end{array}$ & & & & & & & & & & & & & & & & & & $\begin{array}{c}\text { Product and } \\
\text { Technology Diversity } \\
\text { (A4.2) }\end{array}$ \\
\hline
\end{tabular}


Table A24. Perpetual period.

\begin{tabular}{|c|c|c|c|c|c|c|c|c|c|c|c|c|c|c|c|c|c|c|}
\hline \multirow{3}{*}{$\begin{array}{l}\text { Sub-Factors of Niche } \\
\text { Creation }\end{array}$} & \multicolumn{17}{|c|}{ Nominal Scale } & \multirow{3}{*}{$\begin{array}{l}\text { Sub-Factors of } \\
\text { Niche Creation }\end{array}$} \\
\hline & 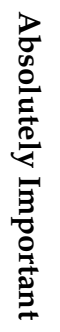 & & 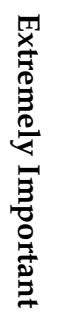 & & 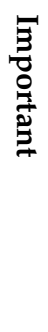 & & 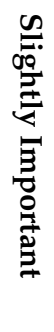 & & 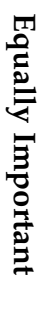 & & 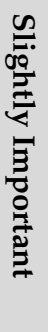 & & 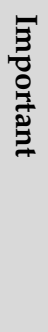 & & 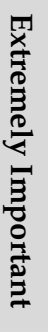 & & 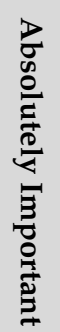 & \\
\hline & 9 & 8 & 7 & 6 & 5 & 4 & 3 & 2 & 1 & 2 & 3 & 4 & 5 & 6 & 7 & 8 & 9 & \\
\hline $\begin{array}{c}\text { Manufacturer } \\
\text { Diversity (A4.1) }\end{array}$ & & & & & & & & & & & & & & & & & & $\begin{array}{c}\text { Product and } \\
\text { Technology Diversity } \\
\text { (A4.2) }\end{array}$ \\
\hline
\end{tabular}

Appendix A.5. Basic Background Information

Thank you for taking the time to complete this questionnaire. Please leave your relevant answers. Please rest assured that your data will not be published in the paper.

1. Your basic information:

Name: Company Name:

Company: Title: Years of Experience:

2. Thank you very much for completing this questionnaire. If you have any comments, please kindly write them below. I will refer to your suggestions to improve the depth and breadth of this study.

This concludes the questionnaire. Please confirm that all questions and personal data have been completed.

Thank you for your support and assistance in this study

I wish you all the best

\section{References}

1. SMEs White Paper; Ministry of Economic Affairs, Small and Medium Enterprise Administration: Taipei, Taiwan, 2016. Available online: https: / / www.moeasmea.gov.tw/article-en-2572-4273 (accessed on 20 July 2021).

2. SMEs White Paper; Ministry of Economic Affairs, Small and Medium Enterprise Administration: Taipei, Taiwan, 2020. Available online: https:/ /book.moeasmea.gov.tw /book/doc_detail.jsp?pub_SerialNo=2020A01655\&click=2020A01655 (accessed on 20 July 2021).

3. Liu, R.J. Division of Labor Network-Analysis of the Mysteries of Taiwan's Machine Tool Industry Competitiveness; Linking Publishing Company: Taipei, Taiwan, 1999.

4. Chen, H.F. Victor Taichung Machinery: Business Ecosystem and the Keystone. J. Inf. Manag. 2008, 15, 1-20.

5. Krugman, P. Increasing Returns and Economic Geography. J. Political Econ. 1991, 99, 483-499. [CrossRef]

6. Porter, M.E. Clusters and the New Economics of Competition. Harv. Bus. Rev. 1998, 76, 77-90.

7. Tallman, S.; Jenkins, M.; Henry, N.; Pinch, S. Knowledge, Clusters and Competitive Advantage. Acad. Manag. Rev. 2004, 29 258-271. [CrossRef]

8. Granovetter, M. Economic Action and Social Structure: The Problem of Embeddedness. J. Econ. Sociol. 2002, 3. [CrossRef]

9. Barnes, C. A Working Social Model? Disability and Work in the 21st Century, the Disability Studies Conference and Seminar; Apex International Hotel: Edinburgh, UK, 1999.

10. Iansiti, M.; Levien, R. Strategy as Ecology. Harv. Bu. Rev. 2004, 82, 68-78.

11. Iansiti, M.; Levien, R. The Keystone Advantage: What the New Dynamics of Business Ecosystems Mean or Strategy, Innovation, and Sustainability; Harvard Business School Press: Boston, MA, USA, 2004.

12. Seigneur, J.M. Demonstration of Security through Collaboration in the Digital Business Ecosystem. In Proceedings of the Workshop of the 1st International Conference on Security and Privacy for Emerging Areas in Communication Networks-Securecomm, Washington, DC, USA, 21-23 October 2005.

13. Zhao, D.Z.; Li, G. The Mode Choosing of Manufacture Network Organization-Evolution from Network Organization to Business Ecosystem. In Proceedings of the Third International Conference on Electronic Commerce Engineering-Digital Enterprises and Nontraditional Industrialization, Hangzhou, China, 24-27 October 2003; pp. 355-359. 
14. Mitleton-Kelly, E. Complex Systems and Evolutionary Perspective on Organizations: The Application of Complexity Theory to Organizations; Pergamum: Oxford, UK, 2003.

15. Furman, J.L.; Porter, M.E.; Stern, S. The determinants of national innovative capacity. Res. Policy 2002, 31, 899-933. [CrossRef]

16. Anderson, G. Industry Clustering for Economic Development. Econ. Dev. Rev. 1994, 16, $26-32$.

17. Morgan, K. The Learning Region: Institutions, Innovation and Regional Renewal. Reg. Stud. 1997, 31, 491-503. [CrossRef]

18. Bell, S.J.; Tracey, P.; Jan, B.; Heide, J.B. The Organization of Regional Clusters. Acad. Manag. Rev. 2009, 34, 623-642.

19. Rosenfeld, S. Industrial Strength Strategies: Regional Business Clusters and Public Policy; Aspen Institute: Washington, DC, USA, 1995.

20. Roelandt, T.J.; Den Hertog, P.; Van Sinderen, J.; Van den Hove, N. Cluster Analysis and Cluster Policy in the Netherlands. In Boosting Innovation: The Cluster Approach; OECD Publishing: Paris, France, 1999; Volume 315, pp. 9-23.

21. Crouch, C.; Farrell, H. Great Britain: Falling through the Holes in the Network Concept. In Local Production Systems in Europe: Rise or Demise; Oxford University Press: Oxford, UK, 2001; pp. 154-211.

22. Feser, E.J.; Bergman, E.M. National Industry Cluster Templates: A Framework for Applied Regional Cluster Analysis. Reg. Stud. 2000, 34, 1-19. [CrossRef]

23. Redman, J.M. Understanding State Economies through Industry Studies; Council of Governors' Policy Advisors: Washington, DC, USA, 1994.

24. Enright, M.J. Regional Clusters and Economic Development: A Research Agenda. In Business Networks: Prospects for Regional Development; Staber, U., Schaefer, N., Sharma, B., Eds.; Walter de Gruyter: Berlin, Germany, 1996; pp. 190-213.

25. Rabellotti, R. Recovery of a Mexican Cluster: Devaluation Bonanza or Collective Efficiency. World Dev. 1999, 27, 1571-1586. [CrossRef]

26. Markusen, A. Sticky Places in Slippery Space: A Typology of Industrial Districts. Econ. Geogr. 1996, 72, 293. [CrossRef]

27. Wang, S.W. Research on Innovation and Strategic Development of Small and Medium Enterprises Clusters; Issues Related to the 2018 SMEs White Paper Compiling Plan; Chung-Hua Institution for Economic Research: Taipei, Taiwan, 2008.

28. Chen, Y.C. Proposal on Taiwan's SME Cluster Counseling and Policy Tools; Institute for Information Industry: Taipei, Taiwan, 2007.

29. Jia, M.J.; Cai, J.R. Discussion on the Development Stages of Enterprise Clusters. Soft Sci. Technol. 2004, 18 , 83-87.

30. SME Digital Care Program; Ministry of Economic Affairs, Small and Medium Enterprise Administration: Taipei, Taiwan, 2013.

31. Li, Y.-R. The technological roadmap of Cisco's business ecosystem. Technovation 2009, 29, 379-386. [CrossRef]

32. Moore, J.F. Predators and prey: A new ecology of competition. Harv. Bus. Rev. 1993, 71, 75-86.

33. Moore, J.F. The Death of competition: Leadership and Strategy in the Age of Business Ecosystems; Harper Business: New York, NY, USA, 1996.

34. Kandiah, G.; Gossain, S. Reinventing value: The new business ecosystem. Strat. Leadersh. 1998, 26, 28-33. [CrossRef]

35. Power, T.; Jerjian, G. Ecosystem: Living the 12 Principles of Networked Business; Financial Times Management: London, UK, 2001.

36. Peltonemi, M.; Vuori, E. Business Ecosystem as the New Approach to Complex Adaptive Business Environments; Frontier of e-Business Research: Tampere, Finland, 2004.

37. Lo, Y.C. Supplementary Business Administration Report. Economic Daily News, 10 July 2004.

38. Adner, R.; Kapoor, R. Value Creation in Innovation Ecosystems: How the Structure of Technological Interdependence Affects Firm Performance in New Technology Generations. Strateg. Manag. J. 2010, 31, 306-333. [CrossRef]

39. Kuo, G.; Seetoo, D.H.; Yu, C.M. Niche Players' Strategic Changes in the Business Ecosystem: The Case of Information Security Software Firms. Fu Jen Manag. Rev. 2010, 17, 1-38.

40. Takata, T. Platform Management Strategy in Different Network Externality Conditions. Yokohama J. Soc. Sci. 2009, 14, 131-149.

41. Kim, K.C.; Song, C.S.; Rhee, J.O. The Healthiness of Business Ecosystem and Its Effect on SME's Performance; International Council for Small Business: Washington, DC, USA, 2010; pp. 1-17.

42. den Hartigh, E.; Tol, M.; Visscher, W. The Health Measurement of a Business Ecosystem. In Proceedings of the European Network on Chaos and Complexity Research and Management Practice Meeting, Bergen aan Zee, The Netherlands, 20-21 October 2006; pp. 1-39.

43. Paine, R. A Conversation on Refining the Concept of Keystone Species. Conserv. Biol. 1995, 9, 962-964. [CrossRef]

44. Hernita, H.; Surya, B.; Perwira, I.; Abubakar, H.; Idris, M. Economic Business Sustainability and Strengthening Human Resource Capacity Based on Increasing the Productivity of Small and Medium Enterprises (SMEs) in Makassar City, Indonesia. Sustainability 2021, 13, 3177. [CrossRef]

45. Wieland, A.; Wallenburg, C.M. Dealing with Supply Chain Risks: Linking Risk Management Practices and Strategies to Performance. Int. J. Phys. Distrib. Logist. Manag. 2012, 42, 887-905. [CrossRef]

46. Alippi, C. Intelligence for Embedded Systems; Springer: Berlin, Germany, 2014. [CrossRef]

47. Saenz, M.J.; Koufteros, X.; Durach, C.F. Antecedents and dimensions of supply chain robustness: A systematic literature review. Int. J. Phys. Distrib. Logist. Manag. 2015, 45, 118-137.

48. Iyer, A.K.; Khaled, G.; Fang, J.; Maeda, H. Exploiting the enhanced permeability and retention effect for tumor targeting. Drug Discov. Today 2006, 11, 812-818. [CrossRef]

49. Dedehayir, O.; Mäkinen, S.J.; Ortt, J.R. Roles during innovation ecosystem genesis: A literature review. Technol. Forecast. Soc. Chang. 2018, 136, 18-29. [CrossRef] 
50. Choi, Y.; Choi, M.; Kim, M.; Ha, J.-W.; Kim, S.; Choo, J. StarGAN: Unified Generative Adversarial Networks for Multi-domain Image-to-Image Translation. In Proceedings of the IEEE Conference on Computer Vision And Pattern Recognition, Salt Lake City, UT, USA, 18-23 June 2018; pp. 8789-8797. [CrossRef]

51. Kannangara, S.N.; Uguccioni, P. Risk Management in Crowdsourcing-based Business Ecosystems. Technol. Innov. Manag. Rev. 2012, 3, 12. [CrossRef]

52. Lappi, O.; Rinkkala, P.; Pekkanen, J. Systematic Observation of an Expert Driver's Gaze Strategy-An on-Road Case Study. Front. Psychol. 2017, 8, 620. [CrossRef] [PubMed]

53. Vargo, C.J.; Guo, L.; A Amazeen, M. The agenda-setting power of fake news: A big data analysis of the online media landscape from 2014 to 2016. New Media Soc. 2017, 20, 2028-2049. [CrossRef]

54. Naghadehi, M.Z.; Mikaeil, R.; Ataei, M. The application of fuzzy analytic hierarchy process (FAHP) approach to selection of optimum underground mining method for Jajarm Bauxite Mine, Iran. Expert Syst. Appl. 2009, 36, 8218-8226. [CrossRef]

55. Saaty, T.L. The Analytic Hierarchy Process; McGraw-Hill International: New York, NY, USA, 1980. 